\title{
Evolution of Early Pleistocene fluvial systems in central Poland prior to the first ice sheet advance - a case study from the Bełchatów lignite mine
}

\author{
Jan Goździk \& Tomasz Zieliński² \\ ${ }^{1}$ Łódź University, Faculty of Geographical Sciences, Narutowicza 88, 90-139 Łódź, Poland \\ ${ }^{2}$ Adam Mickiewicz University, Faculty of Geographical and Geological Sciences, Krygowskiego 12, 60-101 Poznań, \\ Poland \\ *corresponding author, e-mail: gozdzik@geo.uni.lodz.pl
}

\begin{abstract}
Deposits formed between the Neogene/Pleistocene transition and into the Early Pleistocene have been studied, mainly on the basis of drillings and at rare, small outcrops in the lowland part of Polish territory. At the Bełchatów lignite mine (Kleszczów Graben, central Poland), one of the largest opencast pits in Europe, strata of this age have long been exposed in extensive outcrops. The present paper is based on our field studies and laboratory analyses, as well as on research data presented by other authors. For that reason, it can be seen as an overview of current knowledge of lowermost Pleistocene deposits at Bełchatów, where exploitation of the Quaternary overburden has just been completed. The results of cartographic work, sedimentological, mineralogical and palynological analyses as well as assessment of sand grain morphology have been considered. All of these studies have allowed the distinction of three Lower Pleistocene series, i.e., the Łękińsko, Faustynów and Krzaki series. These were laid down in fluvial environments between the end of the Pliocene up to the advance of the first Scandinavian ice sheet on central Poland. The following environmental features have been interpreted: phases of river incision and aggradation, changes of river channel patterns, source sediments for alluvia, rates of aeolian supply to rivers and roles of fluvial systems in morphological and geological development of the area. The two older series studied, i.e., Łękińsko and Faustynów, share common characteristics. They were formed by sinuous rivers in boreal forest and open forest environments. The Neogene substratum was the source of the alluvium. The younger series (Krzaki) formed mainly in a braided river setting, under conditions of progressive climatic cooling. Over time, a gradual increase of aeolian supply to the fluvial system can be noted; initially, silt and sand were laid down, followed by sand only during cold desert conditions. These fluvio-periglacial conditions are identified in the foreground of the advance of the oldest ice sheet into this part of central Poland. The series studied have been compared with other fluvial successions which accumulated in the Kleszczów Graben during subsequent glaciations so as to document general changes in fluvial systems as reactions to climatic evolution. Thus, a palaeoenvironmental scenario has emerged which could be considered to be characteristic of central Poland during the Early Pleistocene.
\end{abstract}

Key words: Quaternary, preglacial, fluvial-aeolian interaction, heavy minerals, quartz grain morphology, sedimentology, palaeoclimate

\section{Introduction}

Issues of deposition and palaeogeographical reconstructions of the Pliocene/Pleistocene transition in central Poland have been studied for almost one hundred years. Despite these research efforts, many questions remain unanswered and the age of the stratigraphic units distinguished still is being revised (compare Bujak et al., 2016; Marks et al., 2016). A precise dating of lower Pleistocene deposits, as 


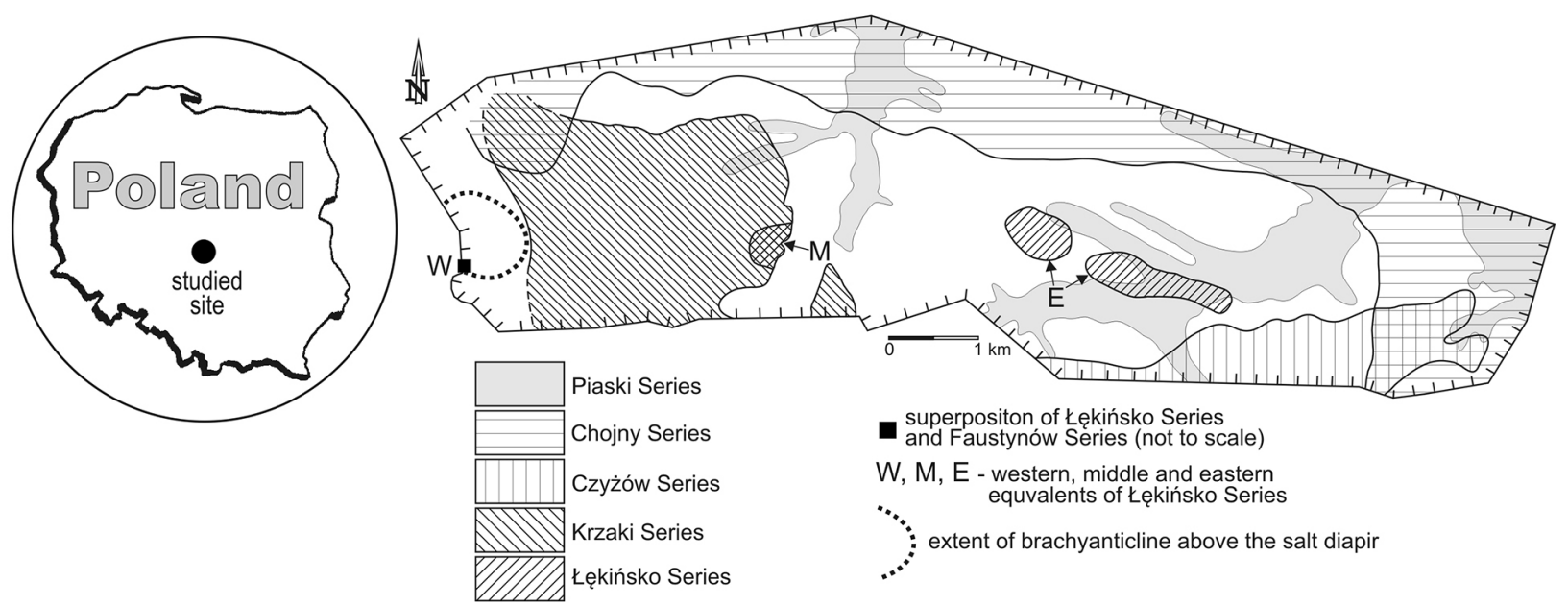

Fig. 1. Sketch of the Bełchatów lignite mine and extent of Pleistocene fluvial series.

well as an evaluation of climatic changes at the time are fraught with difficulties. In this respect, the best chronostratigraphic data derive from those deposits that represent continuous and long-lasting records such as marine and lacustrine facies, whereas the chronostratigraphic and biostratigraphic role of fluvial strata are severely limited. A good example of these are the critical studies by Donders et al. (2007) and Kemna \& Westerhoff (2007) of chronostratigraphic units that had been subdivided by Zagwijn $(1960,1992)$ in continental successions of northwest Europe. Fluvial sedimentary records are fragmentary only, because they contain numerous hiatuses. Diachronic alluvial deposits can be present at the same hypsometric levels due to lateral migration of river channels. Organic matter is relatively rare in such facies. Moreover, it is frequently redeposited and therefore useless for biostratigraphic analyses. On the other hand, fluvial successions are good archives for palaeoenvironmental (including palaeoclimatic) data. As such, they can be treated as a supplementary tool for chronostratigraphic studies.

During the Pliocene and Early Pleistocene fluvial sedimentation prevailed in central Poland. Lacustrine deposits have been found only at some sites, for example at Wólka Ligęzowska in the Mazovian Lowland. A palynological study of this succession (Winter, 2015) has enabled the distinction of deposits of Pliocene (both Zanclean and Piacenzian) and earliest Pleistocene (most likely Praetiglian) age. This site is important because it facilitates correlation of other sections of Neogene/Quaternary age in this part of Poland.

Glacial and glaciofluvial erosion removed Lower Pleistocene deposits over large areas, but those that are preserved usually have a thick Pleistocene cover. Outcrops with Lower Pleistocene successions are extremely rare. For these reasons, field obser- vations of oldest Quaternary deposits are limited; in such circumstances, it is quite normal that most data derive from boreholes and that lithological data are incomplete (compare Marks et al., 2016).

A unique opportunity presented itself to study Neogene and Lower Quaternary deposits at the large $(3 \times 12 \mathrm{~km})$ opencast Bełchatów mine to a depth of c. 200 metres below ground level. The site studied is located within a tectonic graben. Its sedimentary infill encompasses numerous series of various facies, origin and age. They have been the subject of interest of numerous researchers, both Polish and foreign. Tens of studies have been published to date. Sedimentary successions have been documented both vertically and laterally since 1977, as outcrops at the mine progressed. In this way, a three-dimensional, spatial geological structure could be studied.

It is significant that one of the first Polish studies of preglacial (lower Pleistocene) deposits were conducted in areas neighbouring the Kleszczów Graben, i.e., the vicinity of Piotrków Trybunalski and Szczerców (Lewiński, 1928; Premik, 1930). In the 1960s, the graben sector was extensively drilled for future brown coal exploitation. Baraniecka \& Sarnacka (1971) attempted to determine the preglacial units in the area. Studying the successions that cropped out at the mine, Krzyszkowski \& Szuchnik (1995) subdivided the oldest Pleistocene deposits in the Kleszczów Graben into the Łękińsko Series. As a result of successive exploitation the next fluvial deposits above the Łękińsko Series were exposed (Fig. 1); these were named the Krzaki Series and preliminary studies of them were published by Goździk et al. (2010).

Now that the removal of Quaternary deposits at Bełchatów has been completed, the time is right for a recapitulation of previous research, both pub- 
lished and unpublished. Added are our own recent studies. The aim of the present paper is to provide a detailed description of lowermost Pleistocene deposits and their palaeoenvironmental interpretation and stratigraphic location with reference to the Neogene and Quaternary succession within the Kleszczów Graben. We have tried to find palaeoenvironmental features of a wider-than-local scale. Our goal in the present study is to determine mutual relationships of lithostratigraphic units, both vertical and lateral. In this way, not only depositional, but also erosional processes during the Early Pleistocene could be reconstructed.

\section{Geological setting}

The Kleszczów Graben is located in the transitional area of the Małopolska Upland and the central Polish Lowlands. Brown coal is exploited at the Bełchatów open cast mine. Jurassic and Cretaceous rocks constitute the basement of Cenozoic strata within the graben and its surrounding areas (Biernat, 1971; Kossowski, 1974; Czarnecki et al., 1992). The upper surface of the Mesozoic basement generally has a northward dip from 220 to $160 \mathrm{~m}$ a.s.l. (Biernat, 1971). It is dissected by the Kleszczów Graben of a westerly-easterly orientation and a depth of nearly $500 \mathrm{~m}$. The graben lies diagonally to the main tectonic units, i.e., the Eódź Trough and the Fore-Sudetic Monocline. Cenozoic development of the graben resulted in valley incision towards the subsiding depression. Fluvial erosion acted most intensively in a direction concordant with the strike of lithostratigraphic units. They are represented by a relatively homogeneous rock spectrum which meant that Neogene deposits are only slightly differentiated both in terms of sand mineralogy and gravel petrography. This issue will be discussed below.

The Neogene infilling of the Kleszczów Graben has been subdivided into four informal stratigraphic units, so-called complexes: Sub-coal, Coal, Clayey-coal and Clayey-sandy (Czarnecki et al., 1992). The main part of the Sub-coal Complex is of fluvial origin and is Early Miocene age (Krzyszkowski, 1993), more precisely Eggenburgian/Burdigalian (Szynkiewicz, 2000). The Coal Complex formed in a mire environment, while its uppermost parts present lacustrine carbonaceous deposition (Czarnecki et al., 1992; Krzyszkowski, 1993). The age of this complex is Ottangian, Karpatian and early Badenian/Langhian (Szynkiewicz, 2000). Mire, lacustrine and fluvial deposits have been found in the next Clayey-coal Complex (Krzyszkowski \& Winter, 1996). Stratigraphically, this complex is dated as Badenian, Sarmatian and likely early Pannonian, i.e. from Langhian up to Tortonian (Szynkiewicz, 2000).

Stratigraphic interpretation of the uppermost Clayey-sandy Complex appears less straightforward. Studies by Stuchlik et al. (1990) and Stuchlik \& Szynkiewicz (1998) suggest that these strata formed during the Late Miocene. These are so-called 'brown sands' which underlie Quaternary deposits at Bełchatów. Krzyszkowski \& Szuchnik (1995) studied the organic beds in the top part of the Clayey-sandy Complex and noted that it was difficult to correlate the pollen assemblage from these beds with Pliocene spectra of other Polish sites. Those authors found some similarities to Late Pliocene (cool phase C of Reuverian, sensu Zagwijn) in northwest Europe. Krzyszkowski \& Winter (1996) and Winter (2015) ascertained that the pollen spectrum from organic deposits in the Kleszczów Graben revealed parallels to peat beds from the uppermost Neogene fluvial series of Middle and Late Miocene age.

The formation of the Kleszczów Graben began in the Early Miocene. Sedimentary infill of the graben has been divided into three structural units (Gotowała \& Hałuszczak, 2002). The lower of these comprises Lower and Middle Miocene deposits. An unconformity (erosive) surface forms its top. It has been dated as Late Miocene. The middle structural unit involves the time span between the Late Miocene and Pleistocene, up to the Odranian (Saalian). It is characterised by relatively well-developed deformational structures (Gotowała \& Hałuszczak, 2002). The contact with the upper structural unit is also erosional. Generally, this part of the succession, dated as Saalian to Holocene, is undisturbed. The deposits discussed in the present paper belong to the middle structural unit. Referring in part to Krzyszkowski's (1992) subdivision, three zones have been distinguished with the context of tectonic pattern: southern, middle and northern. In the southern zone, a synclinal fold has been found (Krzyszkowski, 1992; Gotowała \& Hałuszczak, 2002). Westwards it adjoins the brachyanticline (Fig. 2) that formed over the Dębina salt diapir. The northern zone comprises a palaeovalley which was recognised in drillings prior to mining operations (Baraniecka \& Sarnacka, 1971). It is at least $1 \mathrm{~km}$ wide and even up to $150 \mathrm{~m}$ deep. Czarnecki \& Kuszneruk (1993) documented large fossil landslides within it. The palaeovalley floor reaches the Mesozoic basement and the thick infill comprises sands with gravelly-bouldery intrabeds (Baraniecka \& Sarnacka, 1971; Krzyszkowski, 1992). This erosional incision was linked to a glacial period because the palaeovalley infill contains abundant 

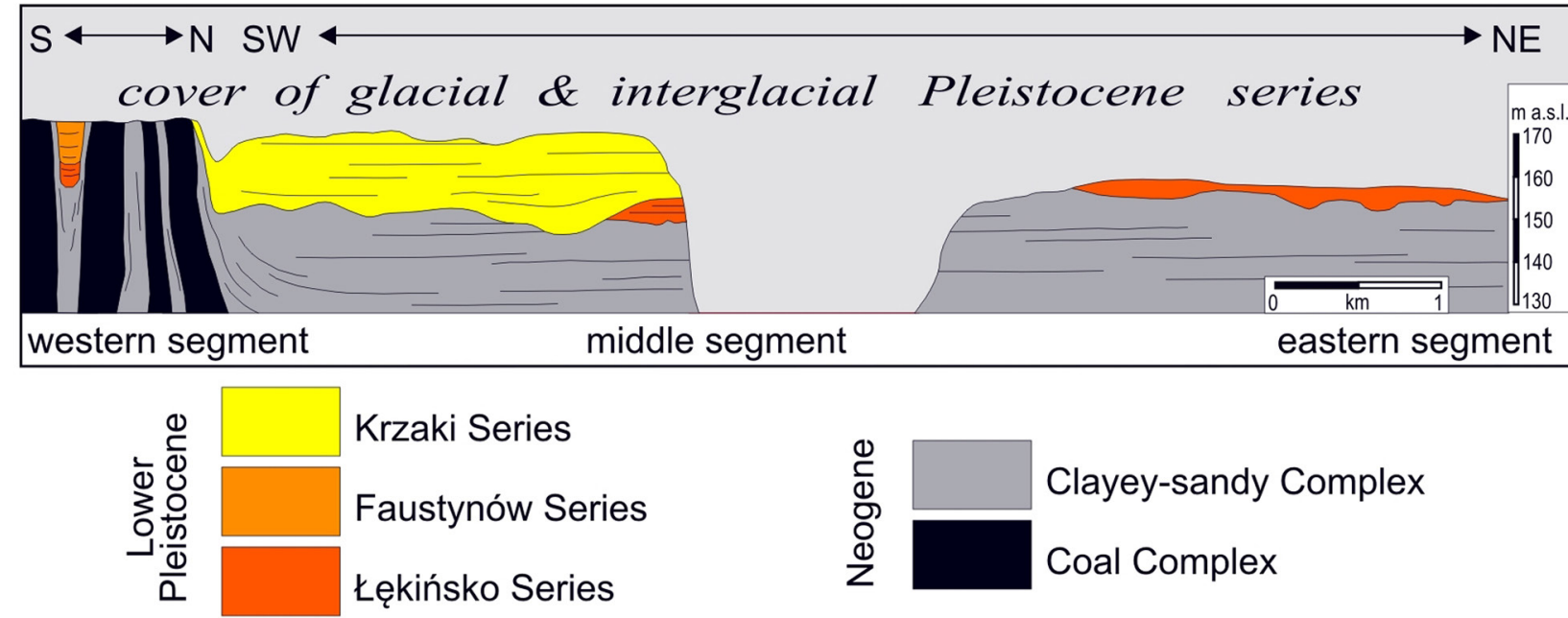

Fig. 2. Synthetic cross section through the Lower Pleistocene series studied.

Scandinavian erratics (Krzyszkowski, 1994 and personal observations). This part of the graben infill is evidently younger than the deposits studied by us. The middle zone is the broadest one and can be differentiated into two distinct parts. In the western part, the top of Neogene deposits is nearly horizontal and overlying Pleistocene deposits are undeformed. In the eastern part, lower Pleistocene deposits are rare because they underwent erosion (Fig. 1). However, in some places the Neogene/
Pleistocene transition has been found at the same altitude and deposits rest horizontally. To conclude, these facts prove that locally in the middle part of the mine, as well as far to the west (except for the salt diapir zone), deposits did not undergo any tectonic movements and are undeformed and in situ. Moreover, there are no features to suggest synsedimentary tectonic activity within the alluvia studied. In fact, lower Pleistocene and younger deposits are folded in the southern part of the mine,

Table 1. Lithostratigraphy of Quaternary deposits at the Bełchatów browncoal mine.

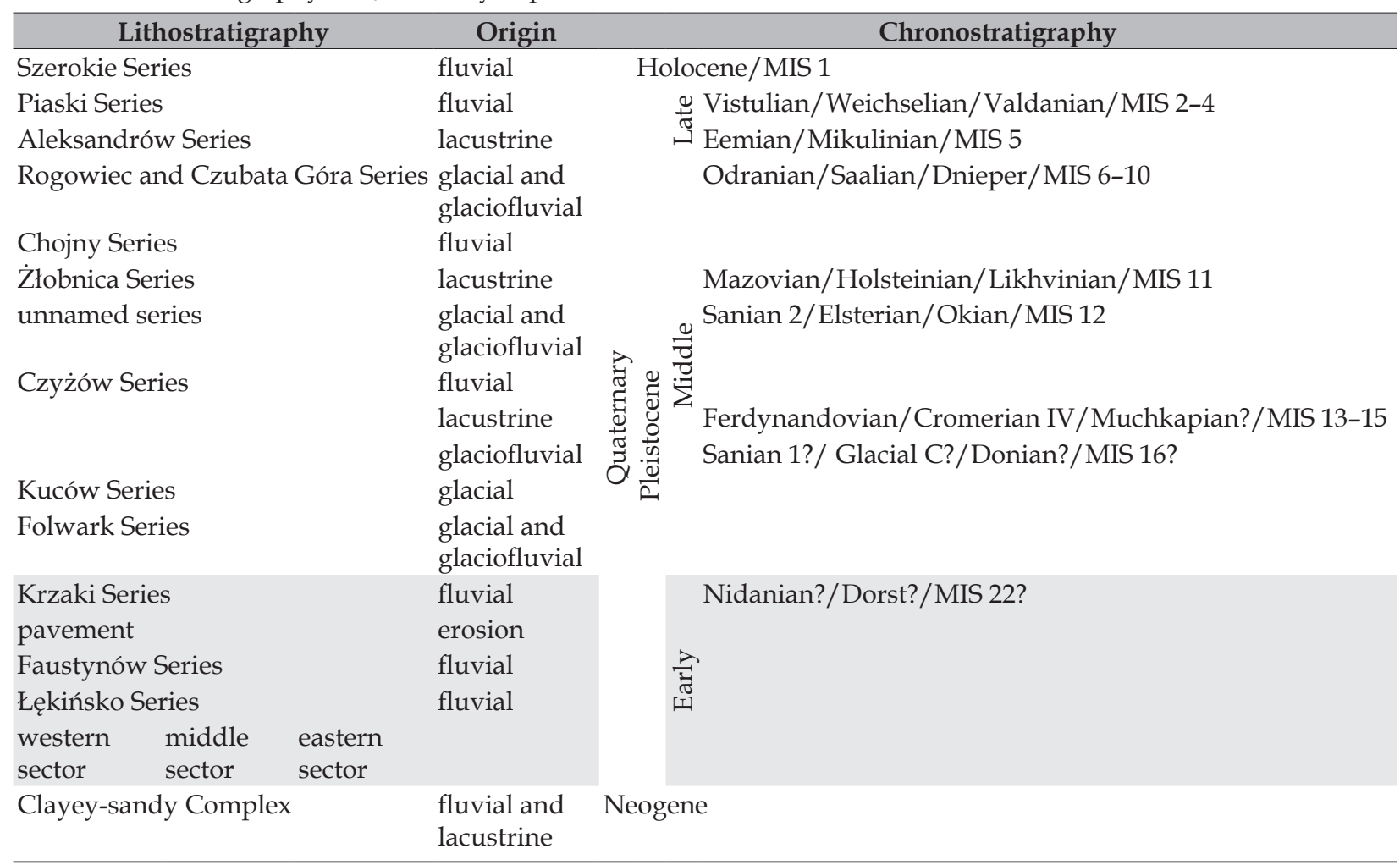


but these deformations arose distinctly later, i.e., immediately prior to the Odranian/Saalian (end of middle Pleistocene).

The presence of Lower Pleistocene deposits in the Kleszczów Graben was first hypothesised by Baraniecka \& Sarnacka (1971). They distinguished thick fluvial deposits that filled the above-mentioned palaeovalley in the northern part of the mine and stratigraphically identified them as the Cromerian Interglacial. However, new data obtained later have led to a revision of this aspect. Krzyszkowski (1994) stated that the deposits were of glaciofluvial origin. Subsequent studies proved that the series mentioned contained deposits of various age and genesis.

In the eastern part of the Bełchatów mine Krzyszkowski \& Szuchnik (1995) identified the lower Pleistocene alluvium as the Łękińsko Series, overlying the Neogene Clayey-sandy Complex. With ongoing exploitation, in the middle part of the mine, other fluvial deposits cropped out above the Neogene Clayey-sandy Complex. Their lithology differed from that of previously distinguished units, so these deposits have been named the Krzaki succession (Goździk, 1999). Four units $\left(K_{1}, K_{2}, K_{3}\right.$ and $\left.\mathrm{K}_{4}\right)$ have been recognised. The lowest one $\left(\mathrm{K}_{1}\right)$ is thin and of small lateral extent. The subsequent three units $\left(\mathrm{K}_{2}, \mathrm{~K}_{3}\right.$ and $\left.\mathrm{K}_{4}\right)$ are thicker and can be traced to the middle and western part of the mine (Goździk, 2001; Goździk et al., 2010). With time, it was noted that two distinct fluvial series existed within this succession. The characteristics of these deposits are presented below.

An assemblage of subsequent glacial and interglacial series overlies the Krzaki succession. Three lower till horizons are divided by glaciofluvial deposits, each of them attaining between a few to a dozen metres in thickness (Goździk, 2001). Two tills belong to the lithostratigraphic units of the Sanian 1 Glaciation (Glacial C), i.e., the Folwark and Kuców Series (Table 1). Organic deposits of the Ferdynandovian Interglacial (Cromerian IV) overlie the till of the Kuców Series (Krzyszkowski et al., 1996). The top of the third till forms a depression that is filled with lacustrine deposits of the Mazovian (Holsteinian) Interglacial, the so-called Żłobnica Series (Balwierz et al., 2008). The next parts of the succession are as follows: the fluvial Chojny Series, glacial Rogowiec Series, glaciofluvial Czubata Góra Series, lacustrine Aleksandrów Series (Eemian) and fluvial Piaski Series (Weichselian) (Table 1). In this Pleistocene stratigraphic model, the Krzaki succession can be regarded as the oldest deposit that is synchronous with the onset of the first advance of a Scandinavian ice sheet into central Poland.

\section{Methods}

The deposits studied were documented by the authors over a dozen of years (1998 to 2014). The faces at the mine were mapped on a yearly basis so as to determine vertical and lateral relationships of fluvial lithosomes. In this way, a 3-D pattern of the series studied could be worked out. In total, 18 vertical profiles have been researched in detail, applying standard sedimentological analysis.Texture, structure, thickness, shape, extent of depositional bodies (lithofacies), as well as contacts between them, have been assessed. Lithofacies have been labelled using Miall (1978) codes, with some modifications (Zieliński \& Pisarska-Jamroży, 2012). Orientation of cross laminae and erosive surfaces have been measured in order to estimate palaeoflow direction and, implicitly, patterns of ancient rivers, an important feature in palaeoclimatic interpretations.

Tens of samples have been collected from all series studied. These have been sieved to prepare material for morphoscopic and mineralogical analyses of sand-sized grains. Roundness has been scored using Krumbein (1941) scale; the morphoscopic method relied on Cailleux (1942). Under optical microscope three principal types of grains shaped in different environments have been distinguished: 1. unworn (non-usés in French) - NU, derived from physical weathering, 2. blunt shining (émoussé-luisant) - EL, from water abrasion, 3. round-matt (rond-mat) - RM, from aeolian abrasion. Included in the RM group are only well-rounded grains, although some grains with lower roundness also indicate aeolian abrasion. The modification of parent Cailleux method involves the distinction of grains with a roundness ratio of $<0.7$ as blunt matt (émoussé-mat) - the EM group (Goździk et al., 2010). Moreover, in the case of some grains their surface is partly matt, partly shiny (i.e. derived from aeolian as well as water environment) which is why they have been subdivided as grains of transitional origin - the T group. In the present study, RM and EL grains are the most important. EL grains, as derived from long-lasting water abrasion, are typical of Neogene deposits. On the other hand, Pleistocene periglacial conditions resulted in a high frequency of RM grains with aeolian abrasion (Cailleux, 1942; Goździk, 1980).

The heavy mineral analysis has been performed on grains of $0.125-0.25 \mathrm{~mm}$ in size and high-density minerals $\left(>2.8 \mathrm{~g} \mathrm{~cm}^{-3}\right)$ separated. The percentage of each heavy mineral has been calculated from a sample of 300-2100 (700 on average) grains (both transparent and opaque). Non-transparent minerals have been identified under a petrographic micro- 
scope and binocular. Fourteen heavy minerals have been identified in the samples analysed. For further interpretation they have been divided into three groups within the context of resistance to weathering: highly resistant (andalusite, kyanite, rutile, sillimanite, staurolite, topaz, tourmaline and zircon), moderately resistant (epidote and garnet) and unresistant (amphibole and pyroxene). Heavy mineral analysis has turned out to be an effective method to evaluate the mineralogical maturity of sands. A predominance of highly resistant minerals has proved long-lasting, multiple redeposition, i.e., indicative of Neogene and lower Pleistocene deposits.

Additionally, the sand samples have been analysed in terms of feldspar presence. Each sample contained at least 300 grains of $0.8-1.0 \mathrm{~mm}$ in size. They have been examined under the binocular. This analysis has enabled to detect a northerly source of these sediments, i.e., a glacial supply of Scandinavian origin.

Our petrographic analysis of gravels has played a similar role. At least 300 clasts coarser than $1 \mathrm{~cm}$ have been examined. The following rock types have been found: white quartz, quartzite, dark lydite, other siliceous rocks, sandstones, igneous and metamorphic rocks. Quartz, lydite and quartzites, as the most resistant types, are typical of local Mesozoic (mainly Cretaceous) bedrock. On the other hand, igneous and metamorphic rocks (Scandinavian erratics) are good indicators of glacial supply.

\section{Lower Pleistocene deposits and their Neogene substratum}

\subsection{Neogene deposits}

Neogene deposits comprise the substratum of the Pleistocene succession in the Kleszczów Graben. The so-called Clayey-sandy Complex (Czarnecki et al., 1992) is the uppermost lithostratigraphic unit of Neogene age. Palynological studies by Winter (Krzyszkowski \& Winter, 1996; Winter, 2015) have proved that its sedimentation finished during the Middle-Late Miocene. An extensive hiatus separates Neogene from Quaternary deposits. Denudation prevailed, which is recorded by the large-scale erosive surface with a distinct pavement.

All Neogene series are characterised by the presence of resistant heavy minerals. The frequency of tourmaline (average and minimum-maximum 37\% and $18-53 \%$, respectively) and kyanite $(31 \%, 10-$ $53 \%)$ are the highest; slightly lower are staurolite $(12 \%, 7-21 \%)$, rutile $(6 \%, 0.5-16 \%)$ and zircon $(6 \%$,
$0.3-25 \%)$. The admixture of less resistant minerals (garnet and epidote) is low. Generally, the percentage of heavy minerals in Neogene deposits is stable, which results from the fact that their content in parent rocks, i.e., Cretaceous sands and sandstones, is nearly the same (Goździk et al., 2010). This view is in agreement with mineralogical analyses by Pękala \& Hycnar (2011) of rocks from the Mesozoic/Cenozoic contact zone in the Kleszczów Graben. Quartz is nearly the single light mineral in Neogene complexes. No feldspars, excluding weathered inclusions within quartz grains, have been found.

The morphology of sand-sized quartz grains is also extremely stable within Neogene deposits. Rounded shiny grains are almost exclusively present. The degree of roundness shows only small deviations from an average 0.516 within all successions. Similar values have been noted from Cretaceous sands in the vicinity of the Kleszczów Graben. This feature points to Cretaceous rocks as source of Neogene deposits (Goździk et al., 2010).

\subsection{Lower Pleistocene alluvia accumulated prior to ice sheet advance to central Poland}

\subsection{1. Łękińsko Series}

The Quaternary succession starts with deposits that have been noted in three sectors of the Belchatów mine.

The eastern sector. In this zone Krzyszkowski \& Szuchnik (1995) documented the Eękińsko Series (Figs. 1, 2), the base of which was found at an altitude of 152-155 $\mathrm{m}$ a.s.l. It has a relatively limited thickness of 1-2 (maximum 5) metres. The Łękińsko Series contains coarse- and medium-grained sands with an admixture of organic detritus, silt, humic silt and peat. The sands form horizontally stratified, rarely cross stratified, beds: the channel river facies. Silty-organic layers have been recognised as overbank facies. Krzyszkowski (1996) interpreted that the environment in which the Łękińsko Series formed was a meandering river. The limited thickness and reduced lateral extent of these deposits resulted from further erosion, mainly by glacial meltwaters that formed deep fossil valleys (Fig. 2). A palynological analysis of organic beds has revealed cool Pleistocene floras. Krzyszkowski \& Szuchnik (1995) evidenced that the heavy-mineral spectrum was nearly the same as in Neogene deposits, only some increase of garnet frequency and sand-grain roundness was noted. They concluded that there was no hiatus between the Neogene Clayey-sandy 


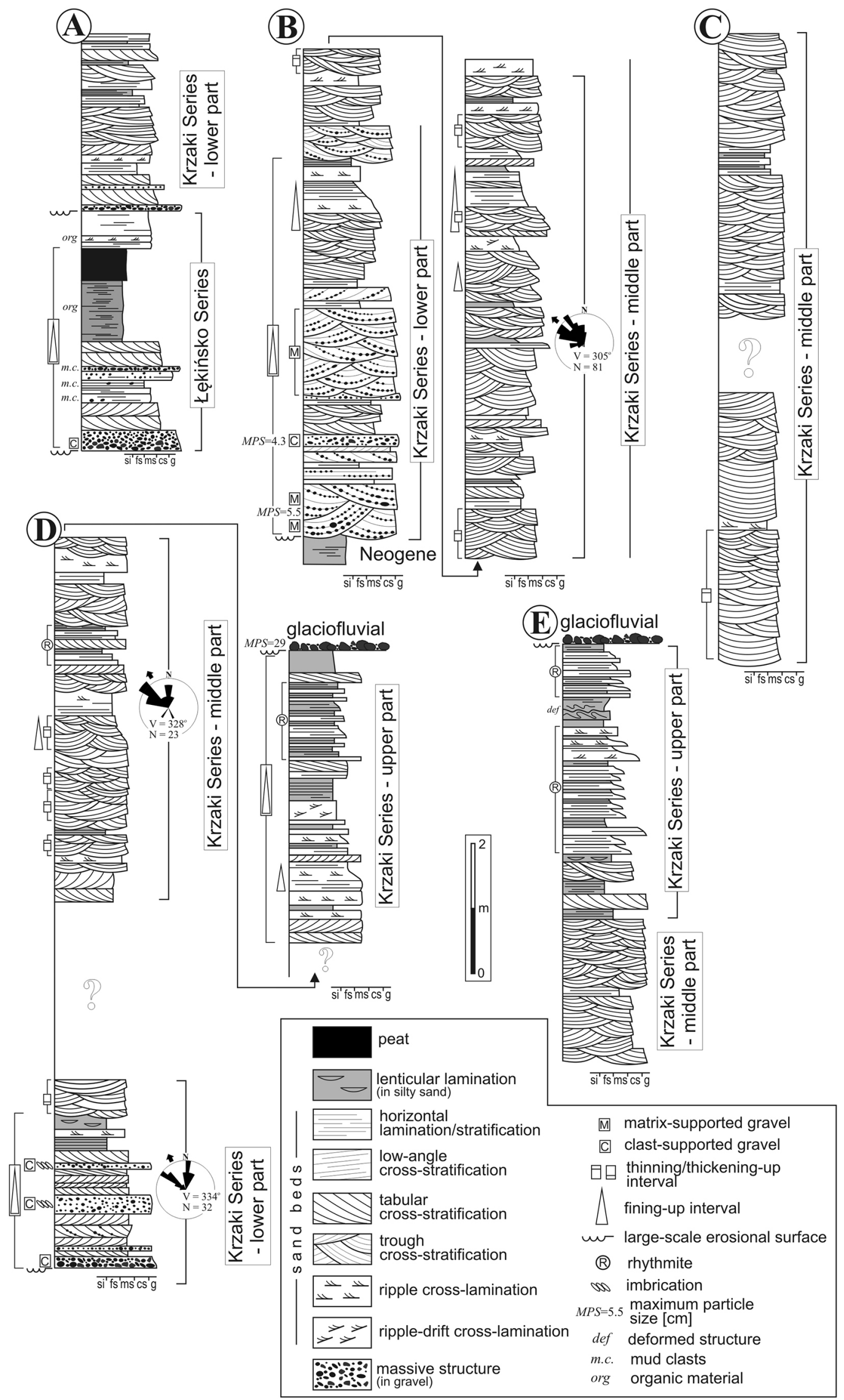


Complex and the Pleistocene Łękińsko Series. However, palynological studies (Krzyszkowski \& Winter, 1996; Winter, 2015) argue against this view. Moreover, we have found evident erosive surface between mentioned units. Krzyszkowski \& Szuchnik (1995) noted an increase of sand-grain roundness in the Łękińsko Series in comparison to the Neogene substratum.

The middle sector. A fluvial unit has been distinguished at a similar altitude in the middle part of the Bełchatów mine (Goździk, 1999). Its base is located at $150 \mathrm{~m}$ a.s.l. and the thickness attained is $4 \mathrm{~m}$ (Fig. 2). The lateral extent of deposits is small due to subsequent erosion. This unit starts from a large-scale erosive surface with a layer of massive gravel $\mathrm{Gm}$ at the base (Fig. 3A). Horizontally laminated humic silt FCh and sand Sh, sand with planar cross stratification $S p$, and peat $C$ predominate. Frequent silt clasts are typical. A relatively high-energy channel coexisted with the floodplain where silt settled in oxbows evolving to mires with peat accretion. These features allow to interpret the sedimentary environment as a wandering river, i.e., a fluvial system transitional between the meandering and braided end members (Miall, 1996; Burge \& Lapointe, 2005). Significantly, wandering rivers frequently develop in catchments with extensive vegetation cover (Nanson \& Knighton, 1996; Bee- chie et al., 2006). The abundant presence of humic silt and peat beds in this unit confirms such an interpretation. It is worth noting that abundant silty clasts dispersed within the beds were derived from the floodplain. Thus, we interpret that this palaeochannel had a sinuous pattern and migrated on the valley floor due to lateral erosion.

Palynological analyses of peat, performed by $\mathrm{Z}$. Janczyk-Kopikowa, have proved that organic accretion took place in an environment of Pleistocene boreal forest (Goździk, 2001). The heavy mineral assemblage is similar to that of the Neogene. Light minerals, predominantly quartz and lacking feldspars, are also typical of Neogene deposits. Moreover, the morphology of quartz grains is nearly the same as in pre-Pleistocene substratum; only a slight increase of rounding and a small admixture of matt grains have been noted (Fig. 4).

The western sector. The Dębina salt diapir is located in the western part of the mine (Fig. 1). Its movement resulted in brachyanticline formation mainly following the Early Miocene and prior to the Quaternary, but also during the Pleistocene (Hałuszczak, 2004). The successions that crop out within the brachyanticline suggest a complex development of this structure with some erosional and depositional phases. During the Early Pleisto-

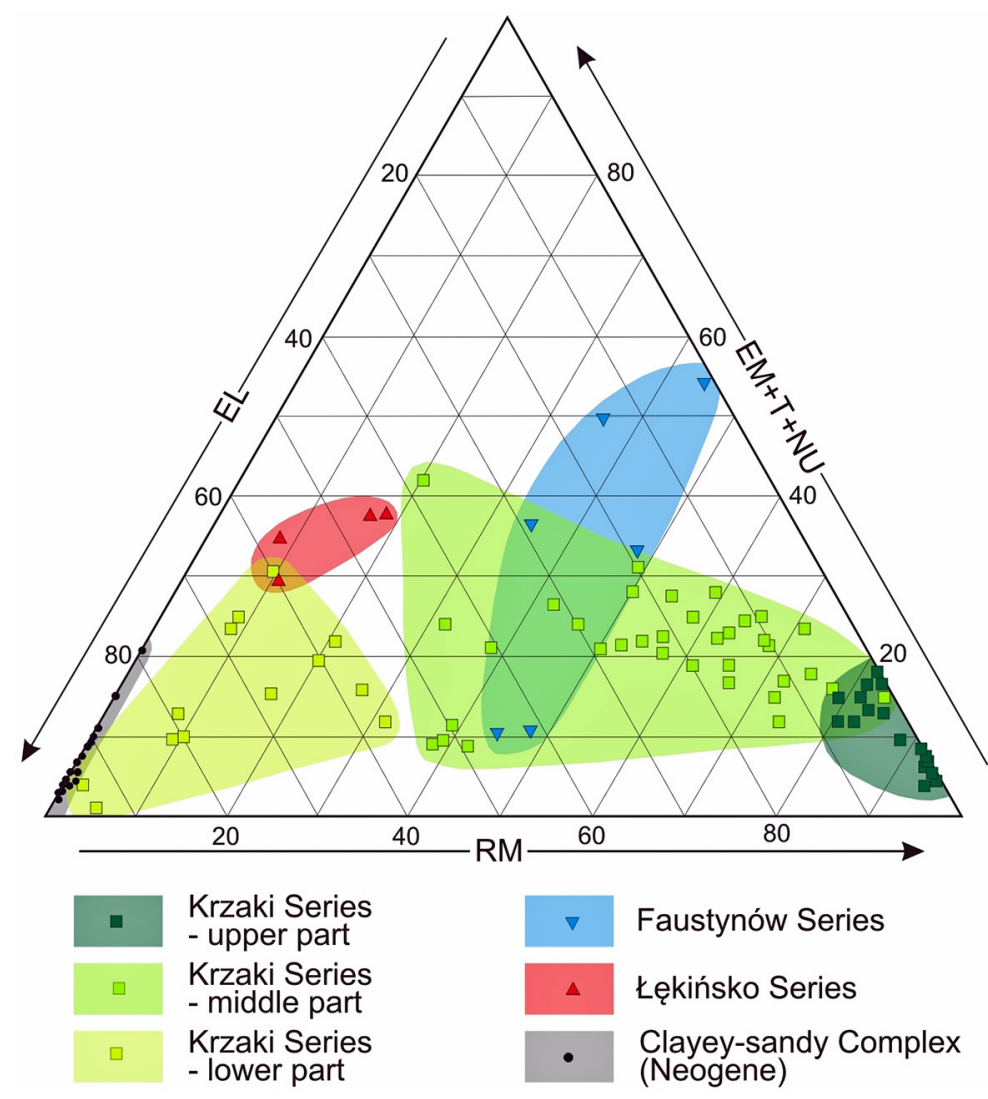

Fig. 4. Morphology of quartz sand grains. EL - rounded, shiny grains (water abrasion); $\mathrm{RM}$ - well-rounded, matt grains (aeolian abrasion); $\mathrm{EM}+\mathrm{T}+\mathrm{NU}$ - other grains (derived from another environment than aeolian or aquatic, or partially abraded in these both environments). There is a clear tendency for the oldest series to be rich in EL-type grains, whereas younger series display an increased content of RM-type grains. 

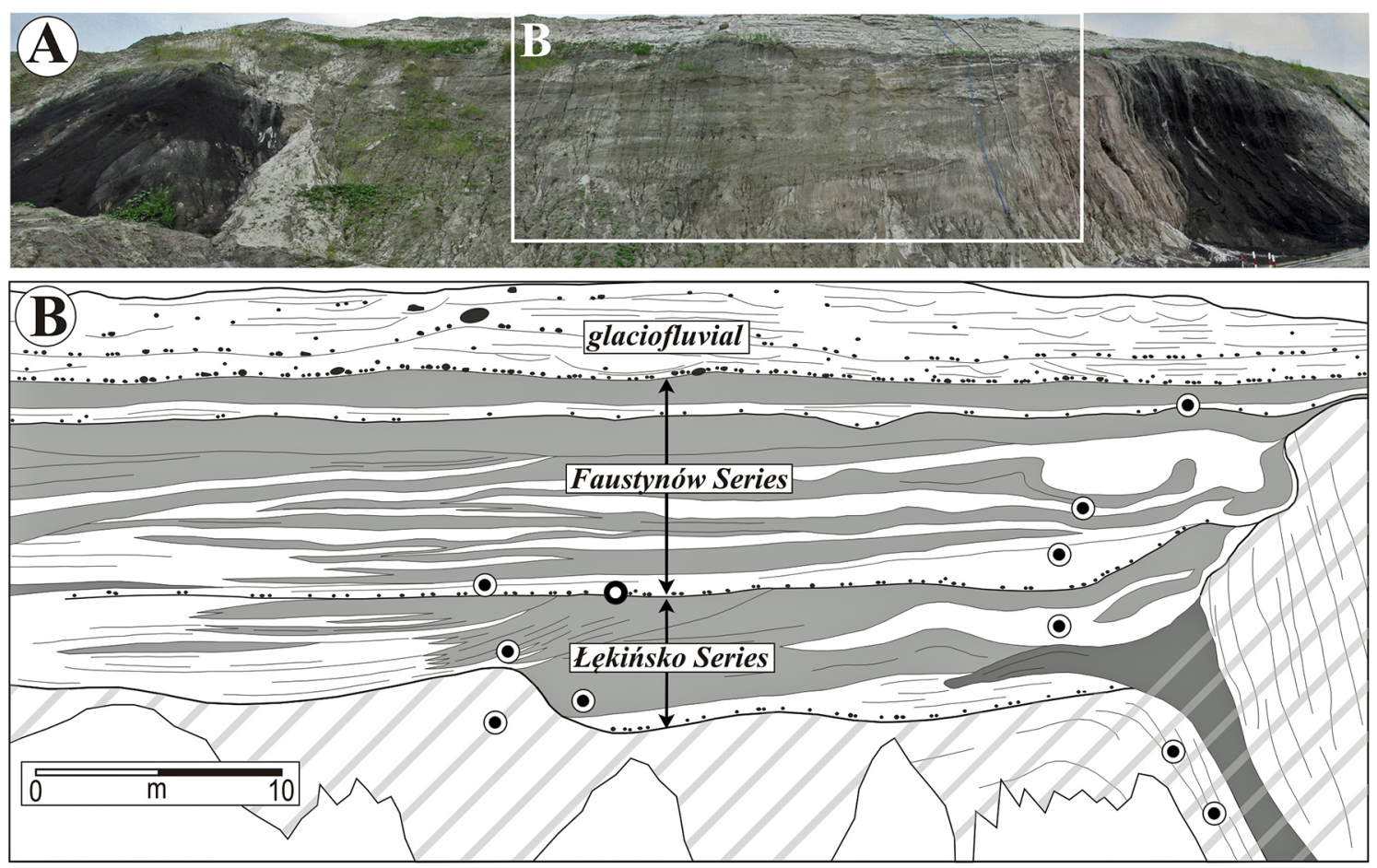

Neogene:

Pleistocene:
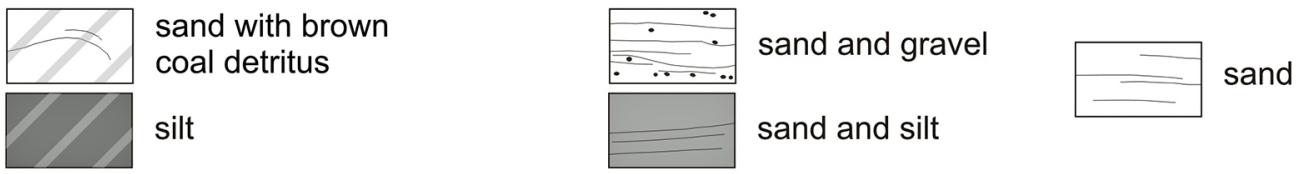

- sand samples for grain morphology and heavy mineral analyses

- gravel sample for petrographic analysis

Fig. 5. Photograph (A) and sketch (B) of deposits that crop out in the westerly portion of the mine, in the vicinity of a salt diapir brachyanticline. For location see Fig. 1; for description see text.

cene a fossil valley was incised into irresistant $\mathrm{Ne}$ ogene sands.

The first phase of sedimentation is represented by a 5.5-m-thick unit (Fig. 5). Its base is the large-scale erosive surface. Lower sandy-gravelly beds pass upwards into interstratified fine-/medium-grained sands and sandy silts. The frequency of fine-grained beds increases upwards. Sandy and silty-sandy sheet-like beds (Sh, FSh) coexist with sandy infills of large channel-like structures. Channel-like beds are approximately $2 \mathrm{~m}$ thick. Sandy and sandy-silty, fining-up infills exhibit low-angle inclined stratification Si concordant to erosive bases (Fig. 5B). We interpret these as epsilon cross stratification, i.e., structures derived from point bars (Gibling \& Rust, 1993). Sheet-like beds are identified to have been formed on the floodplain. Silts settled from suspension in flood basins, whereas sandy intrabeds record the prograding crevasse splays (Farrell, 2001; Bridge, 2003). In summary, we associate these deposits with an environment of a me- andering river, where the channel with point bars adjoined a well-developed floodplain.

Heavy mineral assemblages of these deposits and of the Neogene substratum are similar; resistant minerals predominate. The content of tourmaline is nearly the same, while the percentage of staurolite, zircon and topaz increases in the unit analysed. The highest frequency increase has been noted for garnet, which becomes the dominant mineral towards the top of the succession. This tendency is concomitant with a decrease of kyanite. Within the group of light minerals white quartz comprises over $90 \%$ and the frequency of siliceous rock fragments is not higher than a few percent. Feldspars are lacking. Sand-sized grains are predominantly rounded and shiny ones (EL), similar to the Neogene substratum. On the other hand, a new, atypical feature has been noted; there is some admixture of well-rounded matt grains (RM).

Deposits documented in these three sectors show significant resemblances. They are located at similar altitudes. Although the base of the fluvial interval 
in the western sector is situated c. $5 \mathrm{~m}$ higher than the base of the others (Fig. 2), this minor difference could have resulted from upward movement of the neighbouring salt diapir. Lithological features of these deposits are closely comparable. They formed in sinuous rivers (meandering and wandering) under conditions of a cool climate (boreal forest and forest-steppe). The mineral content of the sands is similar to that of the Neogene substratum, as is sand-grain morphology. All these features justify recognition of these deposits as lateral equivalents of the Łękińsko Series. Deposition of these strata was not synchronous; the sinuous river shifted its channel on the graben floor and deposited alluvia in various zones during several time intervals.

\subsubsection{Faustynów Series}

In the western part of the mine, deposits of the Łękińsko Series have an erosive top that is capped by the pavement (Fig. 5B). Gravels are represented mainly by very well-rounded quartz $(79 \%)$, followed by lydite (9\%) and siliceous rocks (8\%). A rare petrographic group comprises rounded quartz- ites $(2.5 \%)$ and angular sandstones $(1.5 \%)$. The very good rounding of quartz and lydite clasts resulted from long-lived abrasion during former redeposition. This part of succession has an increased zircon content, whereas there is less tourmaline than in underlying and overlying levels. Zircon is one of the most resistant minerals and has a very high density, while tourmaline is also resistant, but of a lower density. In our opinion the high zircon percentage can be explained by its density. Long-lasting redeposition led to increased concentration of this mineral.

The deposits attain $7 \mathrm{~m}$ in thickness. The percentage of sand-sized lithofacies is slightly higher than in the underlying unit. Sandy, sandy-silty and sandy-gravelly sheet beds prevail, whereas the frequency of channel structures is slightly lower. They are also thinner and their widths greater. We interpret the sedimentary environment as a meandering river. However, the palaeochannel was shallower and palaeoflows were of a slightly higher energy. The light mineral assemblage of sands consists practically of quartz alone, with a small admixture of

Table 2. General characteristics and interpretation of Lower Pleistocene deposits studied. For comparison, also the uppermost Neogene complex is presented. Rocks and minerals of secondary frequency are listed in brackets.

\begin{tabular}{|c|c|c|c|c|}
\hline Series & Lithology & Mineralogy and petrography & $\begin{array}{c}\text { Sand-grain morpho- } \\
\text { logy }[\%]\end{array}$ & Fluvial environment \\
\hline $\begin{array}{l}\text { Krzaki: } \\
\text { middle and } \\
\text { upper part }\end{array}$ & $\begin{array}{l}\text { sands, sandy } \\
\text { silt in the top; } \\
\text { gradational } \\
\text { base }\end{array}$ & $\begin{array}{l}\text { sands: } \\
\text { light minerals: quartz, (1-2\% of feldspars) }\end{array}$ & $\begin{array}{l}80<\mathrm{RM}<95 \\
0<\mathrm{EL}<10 \\
5<\mathrm{EM}, \mathrm{T}, \mathrm{NU}<20\end{array}$ & $\begin{array}{l}\text { deep braided river } \\
\text { followed by shallow } \\
\text { abandoned flows, } \\
\text { aeolian supply, flu- } \\
\text { vio-periglacial }\end{array}$ \\
\hline si: & $\begin{array}{l}\text { sands, gravelly } \\
\text { sand, silt; } \\
\text { erosive base }\end{array}$ & $\begin{array}{l}\text { gravels: quartz, lydite, (quartzite, sili- } \\
\text { ceous rocks) } \\
\text { sands: } \\
\text { light minerals: quartz, (siliceous grains) }\end{array}$ & $\begin{array}{l}20<\mathrm{RM}<85 \\
0<\mathrm{EL}<55 \\
10<\mathrm{EM}, \mathrm{T}, \mathrm{NU}<40\end{array}$ & $\begin{array}{l}\text { wandering river, } \\
\text { intensive aeolian } \\
\text { supply of sand and } \\
\text { dust, fluvio-perigla- } \\
\text { cial }\end{array}$ \\
\hline Faus & $\begin{array}{l}\text { sands, silty } \\
\text { sand, gravelly } \\
\text { sand; } \\
\text { erosive base }\end{array}$ & $\begin{array}{l}\text { gravels: quartz, (lydite, siliceous rocks, } \\
\text { quartzite, sandstone) } \\
\text { sands: } \\
\text { light minerals: only quartz; } \\
\text { heavy minerals: tourmaline, staurolite, } \\
\text { kyanite, (garnet, zircon, topaz) }\end{array}$ & $\begin{array}{l}35<\mathrm{RM}<50 \\
0<\mathrm{EL}<45 \\
10<\mathrm{EM}, \mathrm{T}, \mathrm{NU}<55\end{array}$ & $\begin{array}{l}\text { meandering river, } \\
\text { flow energy higher } \\
\text { than in Łękińsko } \\
\text { Series }\end{array}$ \\
\hline $\begin{array}{l}\text { Łękińsko: } \\
\text { western seg- } \\
\text { ment }\end{array}$ & $\begin{array}{l}\text { sands, silty } \\
\text { sand; } \\
\text { erosive base }\end{array}$ & $\begin{array}{l}\text { sands: } \\
\text { light minerals: only quartz; } \\
\text { heavy minerals: tourmaline, staurolite, } \\
\text { garnet, (zircon, topaz) }\end{array}$ & $\begin{array}{l}10<\mathrm{RM}<20 \\
45<\mathrm{EL}<60 \\
30<\mathrm{EM}, \mathrm{T}, \mathrm{NU}<40\end{array}$ & 111 \\
\hline $\begin{array}{l}\text { Eękińsko: } \\
\text { eastern and } \\
\text { middle seg- } \\
\text { ment }\end{array}$ & $\begin{array}{l}\text { sands, organic } \\
\text { silt, peat, grav- } \\
\text { elly sand; } \\
\text { erosive base }\end{array}$ & $\begin{array}{l}\text { sands: } \\
\text { light minerals: quartz, (siliceous grains } \\
\text { sporadically); } \\
\text { heavy minerals: tourmaline, kyanite, } \\
\text { garnet, staurolite, (rutile, zircon) }\end{array}$ & $\begin{array}{l}10<\mathrm{RM}<30 \\
55<\mathrm{EL}<95 \\
0<\mathrm{EM}, \mathrm{T}, \mathrm{NU}<30\end{array}$ & $\begin{array}{l}\text { meandering or wan- } \\
\text { dering river }\end{array}$ \\
\hline $\begin{array}{l}\text { Clayey-sandy } \\
\text { Complex }\end{array}$ & sands, silt, clay & $\begin{array}{l}\text { sands: } \\
\text { light minerals: only quartz; } \\
\text { heavy minerals: tourmaline, kyanite, } \\
\text { (staurolite, rutile, zircon) }\end{array}$ & $\begin{array}{l}\mathrm{RM}=0 \\
80<\mathrm{EL}<100 \\
0<\mathrm{EM}, \mathrm{T}, \mathrm{NU}<20\end{array}$ & $\begin{array}{l}\text { low-energy river and } \\
\text { lake }\end{array}$ \\
\hline
\end{tabular}


siliceous rock fragments. Feldspars were not found. In terms of quartz grain morphology we found an evidently higher frequency of rounded matt grains (RM) (Fig. 4).

These deposits show mineralogical and grain morphological features that are distinctly different from those of the Łękińsko Series (Table 2). On this basis, we consider this fluvial interval to be a separate lithostratigraphic unit, the Faustynów Series. It is also worth noting that sedimentological differences are minor and the rocks and minerals typical of Scandinavian ice sheets are still missing from these deposits.

\subsection{Lower Pleistocene alluvia formed during the first ice sheet advance to central Poland (Krzaki Series)}

Distinct erosive surfaces with a pavement truncate the deposits discussed above. Extensive erosion formed a new palaeovalley which in some places is incised more deeply than the base of Łękińsko Series. It is filled with deposits of up to $24 \mathrm{~m}$ thick, usually around $20 \mathrm{~m}$. Their top is erosive, which means that the original thickness was even greater. The best-preserved alluvium represents the wide, axial zone of the palaeovalley (Fig. 2). The deposits of the marginal valley zones can be studied only locally because they were cleared by erosional processes during younger Pleistocene times. Only a fragment of the eastern palaeovalley slope remained close to the southern margin of the Kleszczów Graben. The western slope has been observed in the vicinity of the Dębina salt diapir (Fig. 1). Glaciotectonic, and partially tectonic, movements during the middle Pleistocene (Bruj \& Krysiak, 2009) led to significant deformations of deposits in the most westerly part of the palaeovalley. No distinct erosive surfaces have been noted within the succession studied. The contacts between the successive portions, presented below, are gradational. Sedimentation took place in a continuous fashion; however, substantial changes of lithological features can be traced within the succession, i.e., the fluvial sedimentary environment was varied.

The initial, mainly erosive phase of palaeovalley development is recorded in gravelly and sandy-gravelly beds of lesser thickness (approximately $1 \mathrm{~m}$, locally $3 \mathrm{~m}$ ) (Fig. 3D). The gravels contain almost exclusively local rocks; Scandinavian material is extremely rare. It seems that the first ice sheet advance is recorded in a thin, discontinuous glacial cover, or more likely, the ice sheet margin reached only the neighbouring area (Goździk, 2001; Goździk et al., 2010). The hypothetical extent of the oldest glaciations (Nidanian, Dorst) is delineated immediately to the south of the Kleszczów Graben (Marks et al., 2016).

Fig. 6. Lower part of the Krzaki Series. Package of sandy-silty rhythmites; the result of overbank sedimentation of a wandering river. The spade is $1.2 \mathrm{~m}$ long.

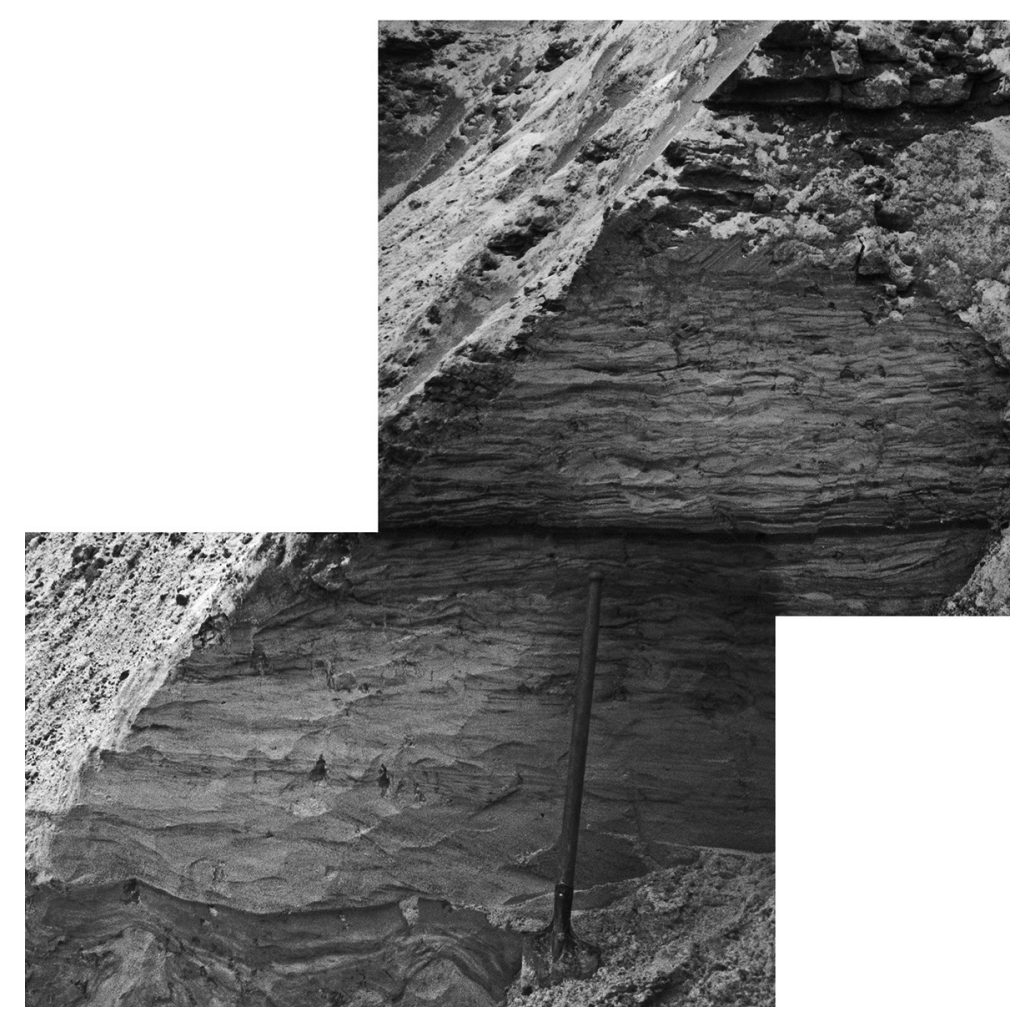


The lower part of the succession measures $c .10$ $\mathrm{m}$ in thickness and is composed of intercalating sandy, sandy-silty and sandy-gravelly beds. More often the sands are medium grained; however, in the basal part coarse-grained sands are abundant. The sands exhibit trough and tabular cross stratifications $(S t, S p)$. There are large, up to 1.1-m-wide troughs, infilled with sand $S e$, but these are rare (Fig. 3B). Sandy-gravelly beds are of sheet shape and massive structure $(S G m)$. Cross strata represent uni- or bimodal distributions with mean vectors in the $305-345^{\circ}$ range (Fig. 3B, D). Fine-grained, sandy-silty beds are horizontally laminated $(S F h)$. In some of them humic detritus has been noted. Peat intercalations have been found sporadically in the basal part of the succession. Extensive packages (up to 2.5-3.0 m thick) of sandy-silty laminites have been found in the marginal zones of palaeovalley fill (Fig. 6). Lenticular sand bodies are horizontally, wavy or ripple laminated. They are intercalated with silty-sand lenses or more continuous sheets of silt. Amongst sand grains quartz predominates, with a low percentage (admixture) of siliceous rocks. Feldspars are absent. The frequency of EL (rounded and shiny) grains diminishes upsection and RM (well-rounded and matt) increases simultaneously (Fig. 4).

We interpret these deposits as recording two fluvial subenvironments. Cross-stratified sands and gravelly sands $(S t, S G t)$ derived from deep river channels. The depth of these palaeoflows is estimated to have been 1.8-1.9 m (see Saunderson \& Jopling, 1980; Bridge, 2003; Villard \& Church, 2005 for palaeohydraulic formulas). Discharges were characterised by large floods which formed thick, channel-like structures Se (compare Hjellbakk, 1997; Pisarska-Jamroży et al., 2010). Another lithofacies association SGm, Sp, FSh is represented by thin beds that reflect deposition in a shallow secondary channel. Relatively intensive flows during short- lived flood pulses aggraded sandy gravels on the upper plane bed $(S G m)$, while waning flows resulted in progradation of sandy foreset bars $(S p)$ and later in channel abandonment (FSh). The thickness of $S p$ beds shows that these secondary channels were not deeper than $0.5 \mathrm{~m}$. Discharges highly fluctuated which is proved by frequent alternation of texturally different beds. In the marginal part of the palaeovalley another fluvial subenvironment has been recorded; here overbank deposition of low-energy sheetflows alternating with standing waters took place. Packages of sandy-silty laminites were formed. The identification of these subfacies (deep and shallow channels, together with floodplain) suggests sandy-gravelly sedimentation in a few channels of low sinuosity (proved by low spread of palaeoflows and the presence of foreset bars), while fine-grained sandy-silty deposits formed in the overbank zone. This architecture points to a fluvial environment that was characterised by features of both braided and meandering rivers. Such a transitional (wandering) fluvial system is represented by intermediate attributes: low channel sinuosity, low braiding index (two or three channels), channel sedimentation derived from braid bars and extensive floodplain with fine-grained accretion (Brierley, 1996; Amsler et al., 2005; Rice et al., 2009).

The middle part of the succession is up to $15 \mathrm{~m}$ thick. It is characterised by a low lithological variability. Medium- and coarse-grained sands of trough cross stratification $S t$ build this unit almost exclusively (Figs. 3C, 7). The cross bed thickness ranges between 10 and $30 \mathrm{~cm}$. Organic admixtures have not been found. RM grains prevail; the frequency of other types is up to $20 \%$. EL-type grains are either lacking or quite sporadic. It is worth noting that the feldspar percentage is low (1-2\%), albeit stable in all samples. This is a characteristic feature, because feldspars are absent from the older deposits (lowermost Pleistocene and Neogene). This is the first part

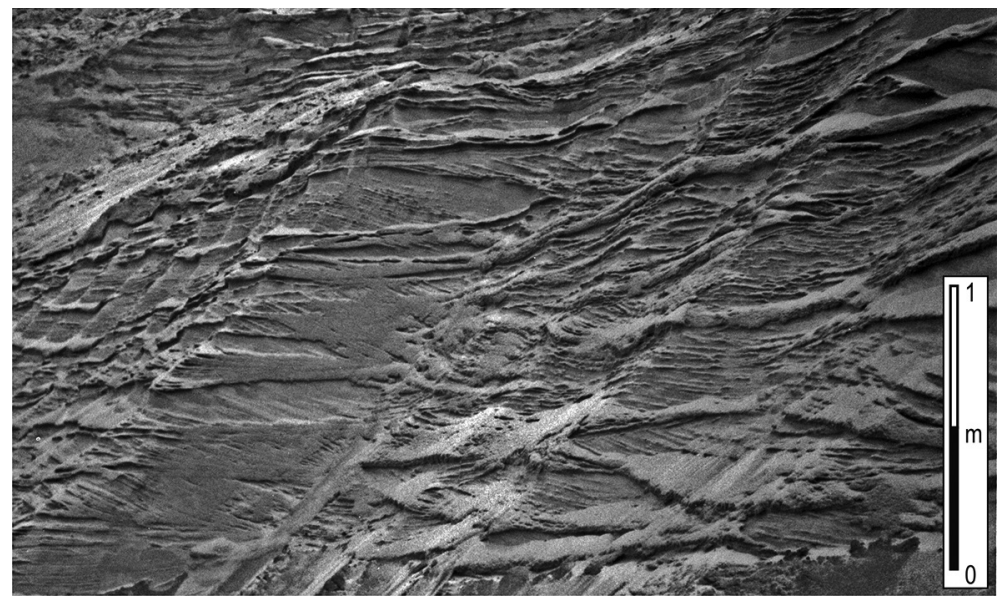

Fig. 7. Middle part of the Krzaki Series. Both texture and structure of deposits are homogeneous; these are medium-/coarsegrained sands with trough cross stratification. The record of sinuous dunes developed in relatively deep channel with rapid flows. Perennial braided river alluvium. 
of the Kleszczów Graben succession in which these minerals appear.

The predominance of $S t$ crossbeds points to a deposition that took place in the way of progradation and burial of sinuous (3D) dunes, the average height of which was 30-60 cm (Harms \& Fahnestock, 1965; Bridge, 2003). They are typical of deep parts of braided channels with relatively fast currents (Perez-Arlucea et al., 2000). The increasing frequency of matt (RM) grains, leading to their ultimate predominance, is interpreted to be the result of long-lasting aeolian redeposition and supply of the fluvial system by wind. Environmental conditions promoted aeolian transport at that time. The absence of organic matter in this unit proves that there was no vegetation cover, or a very sparse one. Moreover, the sands, locally with fine gravels but without silt sizes, are typical sediments that were redeposited on sand-type deserts, also in cold regions. The characteristic presence of feldspars in these deposits suggests that the ice sheet had reached central Poland, but the low content implies that, at the time, it had not got as far as the Kleszczów Graben. It would appear that the feldspar grains were supplied by winds.

The upper part of the succession exists only locally, in places where later erosion was weak. Deposits are relatively fine. Medium- and fine-grained sands show ripple cross lamination ( $S r)$, less often horizontal stratification $(S h)$ or trough and tabular cross stratification (St, Sp) (Fig. 3D). Small-scale sandy-silty rhythmites have been found (Fig. 3E). Frequent sandy-silty rhythmites $S h / S F h$, developed in sheet beds, are attributed to overbank areas between the shallow braided channels. A similar rhythmic development of alternating sandy and silty sheets in overbank facies of braided fluvial systems has been noted from Pleistocene and older sedimentary successions elsewhere (Goździk, 1995; Zieliński \& Goździk, 2001; Therrien, 2006; Łanczont et al., 2010; Zieliński et al., 2015). Ashley \& Hamilton (1993) acknowledged that such rhythmites were characteristic fluvio-periglacial deposits, i.e., overbank facies of braided rivers under conditions of considerable aeolian supply. Organic detritus has been noted in one thin silt layer. Sand-sized quartz grains show the same morphology as in the middle part of the succession (Fig. 4) and feldspar frequency is also similar.

These deposits document a decrease in energy of the fluvial environment. St and $S p$ lithofacies are interpreted as having been derived from a river channel which was shallower in comparison with palaeochannels from deposits beneath, which is corroborated by the lesser thickness of cross beds.

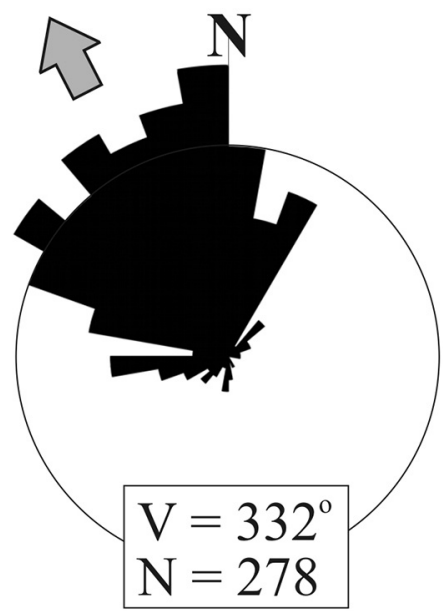

Fig. 8. The Krzaki Series. Total distribution of dip azimuths from cross-stratified beds. The grey arrow signifies the mean direction of river palaeoflow.

The high frequency of rippled sand beds $S r$ indicates lower flow velocities. Sandy-silty rhythmites, developed in sheet beds, are attributed to overbank areas between the shallow braided channels. Similarities of mineralogy and grain morphology of sand suggest that the alluvium of the middle part of the succession as the source for fluvial redeposition or/and aeolian supply was still active.

Characteristic features of the fluvial succession studied that differentiate these deposits from all underlying ones, allow the distinction of individual lithostratigraphic unit (Table 2). These deposits comprise the Krzaki Series, as established by Goździk (1999). They formed in a braided river environment on the foreground of the advancing Scandinavian ice sheet. The river flowed from SSE to NNW (Fig. 8). The units examined in the present study are equivalents of units $\mathrm{K}_{2}, \mathrm{~K}_{3}$ and $\mathrm{K}_{4}$ of previous papers (Goździk, 1999, 2001; Goździk et al., 2010).

\section{Discussion}

\subsection{The series studied as archives of Early Pleistocene and Early/Middle Pleistocene transition}

Observations made along extensive outcrops at Bełchatów have enabled the recognition of several Pleistocene fluvial series within the Kleszczów Graben, as outlined in dozens of previous papers. In particular, the series of Middle and Late Pleistocene age were studied in detail. Up to the present study only one of these was interpreted as a Lower Pleis- 
tocene fluvial deposit, i.e., the so-called Łękińsko Series (Krzyszkowski \& Szuchnik, 1995). Our research supplements the characteristics of these deposits on the basis of new excavations. Moreover, a new Lower Pleistocene fluvial series is established here, the Faustynów Series, which directly overlies the Łękińsko one. Both units were deposited prior to the first ice sheet advance into central Poland. In our opinion, other deposits (Krzaki Series) are synchronous with the oldest ice sheet advance. Thus, new data have been obtained on the development of fluvial systems in this part of Poland during the Early Pleistocene.

During the Neogene, when the tectonic graben came into existence, infill derived from three basic sedimentary systems: fluvial, lacustrine and backswamp (Hałuszczak, 1987; Krzyszkowski \& Winter, 1996). Their role varied during the formation of successive sedimentary complexes. Ever since deposition of the youngest Neogene levels, the Clayey-sandy Complex, the fluvial system became predominant. Small lakes were present only locally, due to a halt of subsidence within the graben. An extensive hiatus exists between the Neogene and Pleistocene series. The 'quiescent' tectonic conditions are confirmed by the flat, wide bottom of the palaeovalley in which Łękińsko Series accumulated. Only along the western margin, close to brachyanticline, does the base of this series lies approximately $5 \mathrm{~m}$ higher, as a result of modest uplift.

Although the non-glacial part of the Pleistocene in central Poland was of long duration, the deposits of this time interval are only sporadically preserved. Most often, these are erosive lags and alluvia which prove that this area was formed mainly by river systems. The relatively limited thickness of fluvial deposits in the Kleszczów Graben results not only from later Pleistocene erosional processes but also from primary environmental conditions. The map of the sub-Quaternary basement (Szmidt, 2012) shows that the part of the Kleszczów Graben studied lies in the axial zone of a large, SSE-NNW oriented trough (azimuth approximately $340^{\circ}$ ). Geological data enable a general palaeomorphological reconstruction of the preglacial valley; it must have been at least $5 \mathrm{~km}$ wide with its bottom at $c .150$ $\mathrm{m}$ a.s.l. (Fig. 2). Long-term fluvial activity formed a relatively flat bottom. Erosional activity of the palaeoriver catchment led to incision of a few tens of metres deep into the upland rocks in a southeasterly direction from the site studied. In our opinion, it is of great importance that the studied reach of the preglacial valley overlaps with the transitional zone between denuded (Małopolska Upland) and aggraded areas (southern Wielkopolska Lowland), where the Kleszczów Graben is located.

On the central Polish lowlands, i.e., the area which is situated lower and to the north of the one studied here, the cover of preglacial deposits is thicker. For example, in the southern Mazowsze Lowland, in the lower reach of the present-day Pilica River, the fluvial series of Early Pleistocene age reaches thicknesses of up to $30 \mathrm{~m}$ (Makowska, 2015). Some lakes, albeit never numerous, existed there. Lacustrine deposits play a significant role as archives for stratigraphic and palaeoclimatic researches of Pliocene and Early Pleistocene in central Poland (Winter, 2015). It is much more difficult to interpret the stratigraphy of Lower Pleistocene fluvial deposits, even when they are thick and contain organic oxbow facies, because such sedimentary records are only fragmentary. For example, Winter (2015, p. 95) noted that "determining of absolute age (...) only on the base of palynological analyses is questionable". It appears that in the light of recent studies of lower Pleistocene deposits (Makowska, 2015; Winter, 2015; Bujak et al., 2016), that for the Ponurzyca succession "which was a key site for the Lower Pleistocene (Baraniecka, 1991), the stratigraphical setting of the deposits remains open" (Marks et al., 2016, p. 409).

Palynological studies of the Łękińsko Series from the Kleszczów Graben have documented a boreal type of vegetation during the Early Pleistocene (Krzyszkowski \& Szuchnik, 1995; Goździk, 2001; Winter, 2015). Krzyszkowski \& Szuchnik (1995) interpreted that sedimentation during the Neogene/ Quaternary transition was continuous, which is why they qualified the Łękińsko Series as lowermost Pleistocene (Pretiglian). In fact, a substantial hiatus between Neogene and Pleistocene deposits has been found in this succession (Krzyszkowski \& Winter, 1996; Winter, 2015). Winter (2015, p. 93) noted for the Łękińsko Series: "In view of fact that some diachronic cool floras are similar in Pleistocene, the stratigraphic assessment of studied deposits is impossible". It is postulated in the present study that the Łękińsko and Faustynów Series formed prior to the first ice sheet advance into central Poland. This observation is based on the position of deposits within the successions studied as well as on mineralogical and morphological features of sand-sized grains. Our analysis shows significant similarities between Neogene and Lower Pleistocene deposits. Glacial-derived elements are lacking. The Łękińsko Series is characterised by a small (albeit crucial for environmental interpretation) frequency of round matt sand grains (RM) that is atypical of Neogene deposits. Their admixture increases in the overlying 
Faustynów Series (Fig. 4). This feature suggests that the aeolian system started gradually to act together with the fluvial one. The precise stratigraphic identification of the onset of aeolian activity is quite difficult. Probably it began during accumulation of the Faustynów Series, or immediately prior to it. This is the first sign of aeolian processes in the study area. Typical aeolian sediments (e.g., cover sands) have not been found in this part of the sedimentary succession. The beginning of accumulation of the Krzaki and Faustynów series is difficult to determine. In our opinion the Faustynów Series, the deposition of which was accompanied by increasing aeolian activity, formed in a period of major climatic changes, i.e., during the so-called Early-to-Middle Pleistocene Transition (EMPT) (Head \& Gibbard, 2015).

The sedimentation of the Łękińsko and Faustynów series was followed by intensive erosional processes forming the valley, together with a pavement cover on its bottom. It is concluded that the final phase of incision and the onset of fluvial infill were climatically controlled. This conclusion matches the views presented by Gao et al. (2007), Vandenberghe (2008), Lewin \& Gibbard (2010) and Cordier et al. (2014) that large-scale river incision was a characteristic process for climatic turns to glaciations. In the Kleszczów Graben the glacial climatic deterioration resulted in a distinct change of the fluvial system. The former meandering river pattern evolved into a braided one; in this sedimentary environment the Krzaki Series was laid down. During that time the study area was located on the foreground of the advancing ice sheet, likely of Nidanian/Dorst (MIS 22) age. Clear evidence of the direct presence of the next ice sheet in the study area is the till that overlies the erosive surface above the Krzaki Series (Goździk, 1999). Most probably it was the ice sheet of Sanian 1 age (Glacial C, MIS 16) that extended far to the south on Polish territory. As a final note, it should be acknowledged that the main environmental change, i.e., the change from a fluvial system to glacial one (or the end of sedimentation of the Krzaki Series) occurred during the transition from Early to Middle Pleistocene.

\subsection{Comparison of the Krzaki Series with other fluvial series at Bełchatów}

In an attempt to understand the changing palaeoenvironmental conditions during the Early Pleistocene better within in the context of later Pleistocene stages, various series of fluvial origin are compared here. These series formed prior to the first ice sheet advance (discussed in detail above) and are of
Middle and Late Pleistocene age: the Czyżów Series (Krzyszkowski, 1991), Chojny Series (Goździk, 1980,1986; Hałuszczak, 1982; Brodzikowski, 1987; Krzyszkowski \& Nita, 1995; Zieliński \& Goździk, 2001) and Piaski Series (Goździk, 1980, 1995; Goździk \& Krzyszkowski, 1987; Krzyszkowski, 1990; Goździk \& Zieliński, 1996; Kasse et al., 1998). Their stratigraphic positions are shown in Table 1.

A clear similarity between the Krzaki Series and the underlying Łękińsko Series is seen in the context of sand grain mineralogy. Quartz has been noted almost exclusively there, with a minor admixture of siliceous rocks. This feature results from the fact that palaeovalleys of both series had the same course. Thus, deposits of the Łękińsko Series were subject to erosion and became the main source of accumulation of the lower part of the Krzaki Series. Some feldspars appear only in the middle and upper part of the Krzaki Series. This feature may be expected as a result of aeolian supply from the oldest glacial deposits that underwent deflation. In terms of the characteristics mentioned, the Łękińsko and Krzaki Series are evidently different from the succeeding ones, the Middle and Upper Pleistocene fluvial series of the Kleszczów Graben. The younger alluvia contain feldspars in significant percentages and an especially high content is noted in their lower parts. This can be linked to the fact that glacial deposits became the main source for the next phases of fluvial redeposition.

In the lower part of the Krzaki Series, sandy-silty rhythmites have been found, with some organic matter in their silty layers. Analogous rhythmites have been noted previously in the middle parts of the Czyżów and Chojny Series and in the lower part of the Piaski Series. Moreover, in the lower parts of all series mentioned the same tendency is typical, namely an upward increase in the frequency of well-rounded and matt grains (RM). This illustrates an intensification of aeolian activity in the course of fluvial sedimentation.

The middle part of the Krzaki Series shows considerable similarities to the upper part of the Chojny and Piaski Series and perhaps to the uppermost part of the Czyżów Series. All these units consist of sands and their lithofacies associations, predominantly in thick cross beds, point to a relatively deep, perennial braided river environment. Almost all grains are well rounded and their surfaces are matt (RM grains abraded by aeolian transport). This indicates that the fluvial system was substantially supplied by wind at that time. Aeolian processes were promoted by the absence or paucity of a vegetation cover, which is proved by the lack of organic matter in the middle part of the Krzaki Se- 
ries, similar to coeval portions of the Chojny and Piaski series which were traced over long distances from the Bełchatów mine. Other important features have been noted in the synchronous upper parts of the Chojny and Piaski series or on the surrounding plains. These are: ventifacts in deflation pavements and aeolian cover sands and sand wedges (Goździk 1980, 1992). They all commonly occur in central Poland and are linked to a polar desert environment (Goździk, 1973; Murton et al., 2000). A comparison of the three fluvial series excavated at Bełchatów leads to the conclusion that each of them formed under similarly severe climatic conditions.

In summary, our comparison of the Krzaki Series with other fluvial units shows the following facts that can be used as a basis for some general inferences. Only few features of the Krzaki Series are close enough to those of the Neogene substratum (Table 2). Upsection, these deposits become increasingly more closely similar to overlying Pleistocene series in terms of lithofacies architecture, sand grain morphology and mineralogy. Based on our research, the nature and evolution of the fluvial system in which the Krzaki Series formed are compatible with those that occurred later in the Middle and Late Pleistocene. During successive glaciations the fluvial system was still active and coexisted with other systems (predominantly glacial and secondarily lacustrine one) in the way of complex relationships. In our opinion, these relationships changed both in time and space in a non-random, cyclic manner. This issue will be the subject of another study.

\section{Conclusions}

The opencast Bełchatów pit in central Poland is an extraordinary locality where strata of nearly the entire Quaternary time span are preserved, including those of Early Pleistocene age. Three lithostratigraphic units comprise the sedimentary record during the early Pleistocene, i.e., the Łękińsko, Faustynów and Krzaki Series, all of which are of fluvial origin.

The Łękińsko and Faustynów Series show numerous similar lithological features and represent palaeoenvironmental links with the underlying Neogene deposits. These Lower Pleistocene and Neogene alluvia are characterised by nearly the same spectrum of heavy minerals: tourmaline, staurolite and kyanite predominate, with significant admixtures of zircon. Sand-sized quartz grains are blunt shining (EL-type derived from transport by water). These prove that Neogene deposits were the source material for the lowest Pleistocene alluvia. They fill deep palaeovalleys and each series starts from a pavement at the base. Sedimentological analysis indicates that the Łękińsko and Faustynów series accumulated in an environment of sinuous, meandering rivers with silty-organic deposition in oxbows on the floodplain. Palynological analyses illustrate boreal forest and forest-steppe in the catchment during formation of the Łękińsko Series.

The upper Krzaki Series represents evident change of palaeoenvironmental conditions. First, the new palaeovalley was incised. Lithological features document the evolution of the fluvial environment from a transitional (wandering) river to relatively deep, perennial, braided system followed by shallow channels with decreasing discharges. The river flowed from SSE to NNW. The analysis of sand grain morphology (a predominance of round and matt grains of RM type) documents the increased aeolian supply to fluvial system at that time. The lack of humic layers confirms formation during severe climatic conditions. We identify the Krzaki Series as a record of a fluvioperiglacial environment in the foreground of the first Scandinavian ice sheet that advanced to central Poland.

Comparison of the series studied with younger fluvial deposits (of Middle and Late Pleistocene age) shows a lot of analogues. Against this background a model of repetitive climate-driven sedimentary cycles can be determined; these will be the subject of another study.

\section{Acknowledgements}

The present study has been supported by a grant from the National Science Centre (NCN) in order to fund a study entitled, 'Pleistocene fluvial and glaciofluvial deposits: lithological characteristics and refinement of existing models' (no Opus 5-Dec_201309BST1000031). Sincere thanks are extended to the Director and Staff of the geological department of the Bełchatów Coal Mine.

\section{References}

Amsler, M.L., Ramonell, C.G. \& Toniolo, H.A., 2005. Morphologic changes in the Parana River channel (Argentina) in the light of the climate variability during the $20^{\text {th }}$ century. Geomorphology 70, 257-278.

Ashley, G.M. \& Hamilton, T.D., 1993. Fluvial response to Late Quaternary climatic fluctuations, central Kobuk Valley, NW Alaska. Journal of Sedimentary Petrology 63, 814-827.

Balwierz, Z., Goździk, J. \& Marciniak, B., 2008. Geneza misy jeziornej i warunki środowiskowe akumulacji limniczno-bagiennej w interglacjale mazowieckim w rowie Kleszczowa (środkowa Polska) [The origin of 
a lake basin and environmental conditions of lacustrine-boggy depositon in the Kleszczów Graben (central Poland) during the Mazovian Interglacial]. Biuletyn Państwowego Instytutu Geologicznego 428, 3-22.

Baraniecka, M.D., 1991. Section Różce against main sections of preglacial deposits in southern Mazowsze. Przeglad Geologiczny 39, 651-665.

Baraniecka, M.D. \& Sarnacka, Z., 1971. Stratygrafia czwartorzędu i paleogeografia dorzecza Widawki [Quaternary stratigraphy and palaeogeography of Widawka catchment]. Biuletyn Instytutu Geologicznego 254, 157-270.

Beechie, T.J., Liermann, M., Pollock, M.M., Baker, S. \& Davies, J., 2006. Channel pattern and river-floodplain dynamics in forested mountain river systems. Geomorphology 78, 124-141.

Biernat, S., 1971. Budowa geologiczna i ukształtowanie podłoża kenozoiku w rejonie Bełchatowa [Cenozoic geology and substrate morphology in Bełchatów area]. Biuletyn Instytutu Geologicznego 254, 37-46.

Bridge, J.S., 2003. Rivers and Floodplains. Forms, Processes, and Sedimentary Record. Blackwell Science (Oxford), 1-491.

Brierley, G.J., 1996. Channel morphology and element assemblages: a constructivist approach to facies modelling. [In:] P.A. Carling \& M.R. Dawson (Eds): Advances in Fluvial Dynamics and Stratigraphy. Wiley \& Sons Ltd., 263-298.

Brodzikowski, K., 1987. Charakterystyka oraz interpretacja paleogeograficzna osadów Formacji Chojny [Lithology and palaeogeographical interpretation of Chojny Formation]. [In:] Czwartorzęd rejonu Betchatowa. II Sympozjum. Plejstoceńskie serie rzeczne i jeziorne oraz bieżące kierunki badań [2 ${ }^{\text {nd }}$ Symposium, Quaternary of Betchatów region'. Pleistocene fluvial and lacustrine series - current researches], Warszawa - Wrocław, 47-62.

Bruj, M. \& Krysiak, Z., 2009. Struktury glacitektoniczne w osadach plejstoceńskich kopalni węgla brunatnego Bełchatów [Glaciotectonic structures in Pleistocene deposits of the Bełchatów brown coal open pit]. Prace Państwowego Instytutu Geologicznego 194, 7-26.

Bujak, Ł., Woronko, B., Winter, H., Marcinkowski, B., Werner, T., Stachowicz-Rybka, R., Żarski, M., Woźniak, P.P. \& Rosowiecka, O., 2016. A new stratigraphic position of some Early Pleistocene deposits in central Poland. Geological Quarterly 60, 238-251.

Burge, L.M. \& Lapointe, M.F., 2005. Understanding the temporal dynamics of the wandering Renous River, New Brunswick, Canada. Earth Surface Processes $\mathcal{E}$ Landforms 30, 1227-1250.

Cordier, S., Frechen, M. \& Harmand, D. 2014. Dating fluvial erosion: fluvial response to climate change in the Moselle catchment (France, Germany) since the Late Saalian. Boreas 43, 450-468.

Czarnecki, L. \& Kuszneruk, J., 1993. Struktury paleoosuwiskowe odsłniete w KWB Bełchatów [Mass movement structures in the Bełchatów brown-coal mine]. Przegląd Geologiczny 41, 841-844.

Czarnecki, L., Frankowski, R. \& Ślusarczyk, G., 1992. Syntetyczny profil litostratygraficzny utworów trzeciorzędowych złoża „Bełchatów” dla potrzeb Bazy danych geologicznych [Synthetic lithostratigraphic profile of 'Bełchatów' Tertiary deposits for the Base of Geological Data]. Górnictwo Odkrywkowe 34, 103-111.

Cailleux, A., 1942. Les actions éoliennes périglaciaires en Europe. Memoir Société Géologique de France 21, 46, 176 pp.

Donders, T.H., Kloosterboer van Hoeve, M.L., Westerhoff, W., Verreussel R.M.C.H. \& Lotter, A.F., 2007. Late Neogene continental stages in NW Europe revisited. Earth-Science Reviews 85, 161-186.

Farrell, K.M., 2001. Geomorphology, facies architecture, and high-resolution, non-marine sequence stratigraphy in avulsion deposits, Cumberland Marshes, Saskatchewan. Sedimentary Geology 139, 93-150.

Gao, C., Boreham, S., Preece, R.C., Gibbard, P.L. \& Briant, R.M., 2007. Fluvial response to rapid climate change during the Devensian (Weichselian) Lateglacial in the River Great Ouse, S England, UK. Sedimentary Geology 202, 193-210.

Gibling, M.R. \& Rust, B.R., 1993. Alluvial ridge-and-swale topography: a case study from the Morien Group of Atlantic Canada. International Association of Ssedimentologists, Spec. Publ. 17, 133-150.

Gotowała, R. \& Hałuszczak, A., 2002. The Late Alpine structural development of the Kleszczów Graben (Central Poland) as a result of reactivation of the pre-existing, regional dislocations. EGU Stephan Mueller Special Publication Series 1, Copernicus Publications (Katlenburg-Lindau), 137-150.

Goździk, J., 1973. Geneza i pozycja stratygraficzna struktur peryglacjalnych $\mathrm{w}$ środkowej Polsce [Origin and stratigraphical position of periglacial structures in Middle Poland]. Acta Geographica Lodziensia 31, 117 pp.

Goździk, J., 1980. Zastosowanie morfoskopii i graniformametrii do badań osadów kopalni węgla brunatnego "Bełchatów" [Analyses of sand-grain morphology in researches of deposits in the 'Bełchatów' browncoal mine]. Studia Regionalne 4, 101-114.

Goździk, J., 1986. Structures de fentes à remplissage primaire sableux du Vistulien en Pologne et leur importance palèogèographique. Biuletyn Peryglacjalny 31, 71-105.

Goździk, J., 1992. Prewarciańskie osady eoliczne w stropie rzecznych utworów formacji "Chojny" w kopalni "Bełchatów" [Pre-Warthian aeolian deposits in the top of Chojny Formation in Bełchatów mine]. Acta Geographica Lodziensia 63, 7-19.

Goździk, J., 1995. Vistulian sediments in the Bełchatów open cast mine, central Poland. Quaternary Studies in Poland 13, 13-26.

Goździk, J., 1999. Sediments of periglacial environment from Pleistocene deposits in Bełchatów open-cast mine. [In:] 'Periglacial environments: past, present and future'. Łódź Periglacial Symposium, 75-82.

Goździk, J., 2001. Stratygrafia i paleogeografia osadów czwartorzędowych w środkowo-zachodniej części kopalni Bełchatów z wykorzystaniem morfoskopii ziarn kwarcowych [Stratigraphy and palaeogeography of Quaternary sediments in central-western part of the mine Bełchatów with the use of quartz grains analysis]. [In:] E. Mycielska-Dowgiałło (Ed.): Eolizacja osadów jako 
wskaźnik stratygraficzny czwartorzędu [Aeolization of sediments as an indicator of Quaternary stratigraphy]. Warsaw University Press, Warszawa, 93-124.

Goździk, J. \& Krzyszkowski, D., 1987. Osady formacji “Piaski" w rejonie kopalni węgla brunatnego "Bełchatów" [Deposits of Piaski Formation in Bełchatów brown-coal mine area]. [In:] Czwartorzęd rejonu Bełchatowa. II Sympozjum. Plejstoceńskie serie rzeczne i jeziorne oraz bieżące kierunki badań [2 ${ }^{\text {nd }}$ Symposium, Quaternary of Betchatów region'. Pleistocene fluvial and lacustrine series current researches], Warszawa - Wrocław: 63-68.

Goździk, J. \& Zieliński, T., 1996. Sedymentologia vistuliańskich osadów małych dolin środkowej Polski - przykład z kopalni Bełchatów [Sedimentology of Vistulian deposits of small valleys in central Poland: a case study from Bełchatów]. Biuletyn Państwowego Instytutu Geologicznego 373, 67-77.

Goździk, J., Kenig, K. \& Skórzak, A., 2010. Zmiany kształtu ziaren kwarcowych oraz składu mineralnego piaszczystych osadów miocenu, pliocenu i niższego czwartorzędu w rowie Kleszczowa [Changes in the shape of quartz grains and mineral composition of Miocene, Pliocene and Lower Quaternary sand deposits in the Kleszczów Graben]. Biuletyn Państwowego Instytutu Geologicznego 438, 33-50.

Hałuszczak, A., 1982. Zarys budowy geologicznej czwartorzędu w rejonie Piaski oraz Buczyna-Chojny. I Sympozjum "Czwartorzęd regionu Bełchatowa" [Outline of Quaternary geology in Piaski and Buczyna-Chojny regions. $1^{\text {th }}$ Symposium, Quaternary of Betchatów region'], Warszawa - Wrocław, 14-35.

Hałuszczak, A., 1987. Zarys litostratygrafii trzeciorzedu rejonu odkrywki Belchatów. II Sympozjum. Plejstoceńskie serie rzeczne i jeziorne oraz bieżące kierunki badań [Outline of Tertiary lithostratigraphy in Betchatów mine area. $2^{\text {nd }}$ Symposium 'Quaternary of Betchatów region'. Pleistocene fluvial and lacustrine series - current researches], Warszawa - Wrocław, 199-205.

Hałuszczak, A., 2004. Cenozoic dynamics of the Dębina Salt Dome, Kleszczów Grabem, inferred from structural features of the Tertiary-Quaternary cover. Annales Societatis Geologorum Poloniae 74, 311-318.

Harms, J.C. \& Fahnestock, R.K., 1965. Stratification, bedforms, and flow phenomena (with an example from the Rio Grande). [In:] G.V. Middleton (Ed.), Primary Sedimentary Structures and their Hydrodynamic Interpretation. Society of Economic Paleontologists and Mineralogists, Spec. Publ. 12, 84-115.

Head, M.J. \& Gibbard, P.L., 2015. Early Middle Pleistocene transitions: Linking terrestrial and marine realms. Quaternary International 290,7-46.

Hjellbakk, A., 1997. Facies and fluvial architecture of a high-energy braided river: the Upper Proterozoic Seglodden Member, Varanger Peninsula, N Norway. Sedimentary Geology 114, 131-161.

Kasse, C., Huijzer, A.S., Krzyszkowski, D., Bohncke, S.J.P. \& Coope, G.R., 1998. Weichselian Late Pleniglacial and Late-glacial depositional environments, Coleoptera and periglacial climatic records from central Poland (Bełchatów). Journal of Quaternary Science 13, 455-469.
Kemna, H.A. \& Westerhoff, W.E., 2007. Remarks on palynlogy-based chronostratigraphical subdivision of Pliocene terrestial deposits in NW-Europe. Quaternary International 164-165, 184-196.

Kossowski, L., 1974. Budowa geologiczna złoża węgla brunatnego Bełchatów ze szczególnym uwzględnieniem tektoniki podłoża [Geology of Bełchatów brown-coal deposit with account of basement tectonics]. Górnictwo Odkrywkowe 16, 336-341.

Krumbein, W.C., 1941. Measurement and geological record significance of shape and roundness of sedimentary particles. Journal of Sedimentary Petrology 11, 64-72.

Krzyszkowski, D., 1990. Middle and Late Weichselian stratigraphy and palaeoenvironments in central Poland. Boreas 19, 333-350.

Krzyszkowski, D., 1991. The Middle Pleistocene polyinterglacial Czyżów Formation in the Kleszczów Graben (central Poland): stratigraphy and paleogeography. Folia Quaternaria 61/62, 5-58.

Krzyszkowski, D., 1992. Quaternary tectonics in the Kleszczów Graben (Central Poland): a study based on sections from the 'Bełchatów' outcrop. Quaternary Studies in Poland 11, 65-90.

Krzyszkowski, D., 1993. Neogene fluvial sedimentation in the Kleszczów Graben, Central Poland. Journal of Sedimentary Petrology 6, 204-217.

Krzyszkowski, D., 1994. A revision of the stratigraphic position of „Wola Grzymalina Series” in The Kleszczów Grben (Central Poland). Quaternary Studies in Poland 12, 5-19.

Krzyszkowski, D., 1996. Climatic control on Quaternary fluvial sedimentation in the Kleszczów Graben, central Poland. Quaternary Science Reviews 15, 315-333.

Krzyszkowski, D. \& Nita, M., 1995. The intra-Saalian interstadial floras of the Chojny Formation of Belchatów, central Poland. Journal of Quaternary Science 10, 225-240.

Krzyszkowski, D. \& Szuchnik, A., 1995. Pliocene-Pleistocene boundary in the Kleszczów Graben at Bełchatów, Central Poland. Journal of Quaternary Science 10, 45-58.

Krzyszkowski, D. \& Winter, H., 1996. Stratigraphic position and sedimentary features of the Tertiary Uppermost Fluvial Member in the Kleszczów Graben, Central Poland. Annales Societatis Geologorum Poloniae 66, 17-33.

Krzyszkowski, D., Böttger, T., Junge, F.W., Kuszell, T. \& Nowicki, J., 1996. Ferdynandovian Interglacial climate reconstructions from pollen successions, stable-isotope composition and magnetic susceptibility. Boreas 25, 283-296.

Lewin, J. \& Gibbard, P.L., 2010. Quaternary river terraces in England: Forms, sediments and processes. Geomorphology 120, 293-311.

Lewiński, J., 1928. Utwory preglacjalne i glacjalne Piotrkowa i okolic [Preglacial and glacial deposits of Piotrków and surroundings]. Sprawozdania z posiedzeń Towarzystwa Naukowego Warszawskiego, Wydz. III 21, 49-66.

Łanczont, M., Bogucki, A., Mroczek, P., Zieliński, P., Jacyszyn, A., Pidek, A.I., Urban, D., Kulesza, P. \& Hołub, B., 2010. Zapis interglacjalno-glacjalnych cykli w sekwencji osadowej w Krużykach nad Dniestrem (Wschodnie Podkarpacie) [Interglacial-glacial cycles 
recorded in the deposit sequence at Kruzhyky on the Dniester River (E Carpathian Foreland)]. Annales UMCS B, 65, 37-56.

Makowska, A., 2015. Budowa geologiczna i stratygrafia formacji preglacjalnej po0łudniowego Mazowsza nad dolna Pilicą [The geological structure and stratigraphy of the preglacial formation in the southern Mazovia region, lower Pilica River area]. Prace Państwowego Instytutu Geologicznego 202, 7-52.

Marks, L., Dzierżek, J., Janiszewski, R., Kaczorowski, J., Lindner, L., Majecka, A., Makos, M., Szymanek, M., Tołoczko-Pasek, A. \& Woronko, B., 2016. Quaternary stratigraphy and paleogeography of Poland. Acta Geologica Polonica 66, 403-427.

Miall, A.D., 1978. Lithofacies types and vertical profile models in braided rivers: a summary. [In:] A.D. Miall (Ed.), Fluvial Sedimentology. Canadian Society of Petroleum Geologists Memoir 5, 597-604.

Miall, A.D., 1996. The Geology of Fluvial Deposits. Sedimentary Facies, Basin Analysis, and Petroleum Geology. Springer (Berlin), $582 \mathrm{pp}$.

Murton, J.B., Worsley, P. \& Gozdzik, J., 2000. Sand veins and wedges in cold aeolian environments. Quaternary Science Reviews 19, 899-922.

Nanson, G.C. \& Knighton, A.D., 1996. Anabranching rivers: their cause, character and classification. Earth Surface Processes Landforms 21, 217-239.

Perez-Arlucea, M., Mack, G. \& Leeder, M., 2000. Reconstructing the ancestral (Plio-Pleistocene) Rio Grande in its active tectonic setting, S Rio Grande rift, New Mexico, USA. Sedimentology 47, 701-720.

Pękala, A. \& Hycnar, E., 2011. Minerały ciężkie w strefie kontaktu mezozoik/kenozoik w złożu węgla brunatnego Bełchatów [Heavy minerals in the Bełchatów lignite deposit from the Mesozoic/Cenozoic contact zone]. Biuletyn Państwowego Instytutu Geologicznego $444,171-176$.

Pisarska-Jamroży, M., Machowiak, K. \& Krzyszkowski, D., 2010. Sedimentation style of a Pleistocene kame terrace from the Western Sudety Mountains, S Poland. Geologos 16, 101-110.

Premik, J., 1930. Badania nad dyluwium województwa łódzkiego. cz. I. O utworach preglacjalnych, glacjalnych i interglacjalnych w dorzeczu środkowej Warty, Widawki i Prosny [Studies on dilluvium of the Łódź district. Part I. Preglacial, glacial and interglacial deposits of Warta, Widawka and Prosna catchments]. Roczniki Polskiego Towarzystwa Geologicznego 6, 382-392.

Rice, S.P., Church, M., Wooldridge, C.L. \& Hickin, E.J., 2009. Morphology and evolution of bars in a wandering gravel-bed river; lower Fraser river, B.C., Canada. Sedimentology 56, 709-736.

Saunderson, H.C. \& Jopling, A.V., 1980. Paleohydraulics of a tabular, cross-stratified sand in the Brampton esker, Ontario. Sedimentary Geology 25, 169-188.

Stuchlik, L. \& Szynkiewicz, A., 1998. General geological situation and palynological investigations of the brown coal deposits. [In:] Tertiary-Quaternary (Pleistocene) floras of Betchatów (Middle Poland) and several localities in South-Western Poland. $5^{\text {th }}$ European Paleobotanical and Palynological Conference. Guide to Excursion 2, 6-11.
Stuchlik, L., Szynkiewicz, A., Łańcucka-Środoń, M. \& Zastawniak, E., 1990. Wyniki dotychczasowych badań paleobotanicznych trzeciorzędowych węgli brunatnych złoża "Bełchatów” [Results of palaeobotanical studies on Tertiary brown-coal deposits ,Bełchatów']. Acta Paleobotanica 30, 295-305.

Szmidt, A., 2012. Wpływ podłoża na rzeźbę i osady czwartorzędu na obszarze województwa łódzkiego w świetle wybranych metod GIS [Relationship of basement to landforms and deposits on Łódź Province area]. Thesis Łódź University, 225 pp.

Szynkiewicz, A., 2000. Wiek węgla brunatnego na tle pozycji geologicznej badanych próbek (KWB „Bełchatow" [Age of the brown coal deposits from Bełchatów lignite mine (central Poland)]. Przegląd Geologiczny 48, 1038-1045.

Therrien, F., 2006. Depositional environments and fluvial system changes in the dinosaur-bearing Sanpetru Fm. (Late Cretaceous, Romania): post-orogenic sedimentation in an active extensional basin. Sedimentary Geology 192, 183-205.

Vandenberghe, J., 2008. The fluvial cycle at cold-warmcold transitions in lowland regions: A refinement of theory. Geomorphology 98, 275-284.

Villard, P.V. \& Church, M., 2005. Bar and dune development during a freshet: Fraser River Estuary, B.C., Canada. Sedimentology 52, 737-756.

Winter, H., 2015. Dynamika zmian klimatycznych w pliocenie i plejstocenie dolnym oraz granica neogen/ czwartorzęd w osadach południowego Mazowsza (środkowa Polska) [The dynamics of climatic changes in the Pliocene and Lower Pleistocene, and the Neogene/Quaternary transition in sediments from S Mazovia (central Poland) on the basis of palynological data]. Prace Państwowego Instytutu Geologicznego 202, 53-106.

Zagwijn, W.H., 1960. Aspects of the Pliocene and Early Pleistocene vegetation in the Netherlands. Mededelingen Geologische Stichting C-III, 1, 1-78.

Zagwijn, W.H., 1992. The beginning of the Ice Age in Europe and its major subdivisions. Quaternary Science Reviews 11, 583-591.

Zieliński, P., Sokołowski, R.J., Woronko, B., Jankowski, M., Fedorowicz, S., Zaleski, I., Molodkov, A. \& Weckwerth, P., 2015. The depositional conditions of the fluvio-aeolian succession during the last climate minimum based on the examples from Poland and NW Ukraine. Quaternary International 386, 30-41.

Zieliński, T. \& Goździk, J., 2001. Palaeoenvironmental interpretation of a Pleistocene alluvial succession in central Poland: sedimentary facies analysis as a tool for palaeoclimatic inferences. Boreas 30, 240-253.

Zieliński, T. \& Pisarska-Jamroży, M., 2012. Jakie cechy litologiczne warto kodować, a jakie nie? [Which features of deposits should be included in the code and which not?]. Przeglad Geologiczny 60, 387-397.

Manuscript received 18 March 2017 Revision accepted 4 July 2017 